\title{
Optical properties of Central Asian aerosol relevant for spaceborne lidar applications and aerosol typing at 355 and $532 \mathrm{~nm}$
}

\author{
Julian Hofer ${ }^{1}$, Albert Ansmann ${ }^{1}$, Dietrich Althausen ${ }^{1}$, Ronny Engelmann ${ }^{1}$, Holger Baars ${ }^{1}$, \\ Khanneh Wadinga Fomba ${ }^{1}$, Ulla Wandinger ${ }^{1}$, Sabur F. Abdullaev ${ }^{2}$, and Abduvosit N. Makhmudov ${ }^{2}$ \\ ${ }^{1}$ Leibniz Institute for Tropospheric Research, Leipzig, Germany \\ ${ }^{2}$ Physical Technical Institute of the Academy of Sciences of Tajikistan, Dushanbe, Tajikistan
}

Correspondence: Julian Hofer (hofer@tropos.de)

Received: 18 March 2020 - Discussion started: 14 April 2020

Revised: 17 June 2020 - Accepted: 3 July 2020 - Published: 6 August 2020

\begin{abstract}
For the first time, a dense data set of particle extinction-to-backscatter ratios (lidar ratios), linear depolarization ratios, and backscatter- and extinction-related Ångström exponents for a Central Asian site are presented. The observations were performed with a continuously running multiwavelength polarization Raman lidar at Dushanbe, Tajikistan, during an 18-month campaign (March 2015 to August 2016). The presented seasonally resolved observations fill an important gap in the database of aerosol optical properties used in aerosol typing efforts with spaceborne lidars and ground-based lidar networks. Lidar ratios and depolarization ratios are also basic input parameters in spaceborne lidar data analyses and in efforts to harmonize longterm observations with different space lidar systems operated at either 355 or $532 \mathrm{~nm}$. As a general result, the found optical properties reflect the large range of occurring aerosol mixtures consisting of long-range-transported dust (from the Middle East and the Sahara), regional desert, soil, and salt dust, and anthropogenic pollution. The full range from highly polluted to pure dust situations could be observed. Typical dust depolarization ratios of $0.23-0.29(355 \mathrm{~nm})$ and 0.30 $0.35(532 \mathrm{~nm})$ were observed. In contrast, comparably low lidar ratios were found. Dust lidar ratios at $532 \mathrm{~nm}$ accumulated around 35-40 sr and were even lower for regional background dust conditions (20-30 sr). Detailed correlation studies (e.g., lidar ratio vs. depolarization ratios, Ångström exponent vs. lidar ratio and vs. depolarization ratio) are presented to illuminate the complex relationships between the observed optical properties and to identify the contributions of anthropogenic haze, dust, and background aerosol to the overall aerosol mixtures found within the 18-month cam-
\end{abstract}

paign. The observation of $532 \mathrm{~nm}$ lidar ratios $(<25 \mathrm{sr})$ and depolarization ratios (around $15 \%-20 \%$ ) in layers with very low particle extinction coefficient $(<30 \mathrm{sr}$ ) suggests that direct emission and emission of resuspended salt dust (initially originated from numerous desiccating lakes and the Aralkum desert) have a sensitive impact on the aerosol background optical properties over Dushanbe.

\section{Introduction}

Central Asia is a hotspot region of severe environmental problems and climate-change effects. Shrinking glaciers and the desiccating Aral Sea are clear and unambiguous signs of a major impact of human activities on the environmental conditions in this area of the world (Kazakhstan, Turkmenistan, Uzbekistan, Kyrgyzstan, Tajikistan). Although a key region of strong environmental changes, observations of aerosol conditions, one of the main indicators for the pollution state, are rare in Central Asia. Trustworthy data sets describing the annual cycle of environmental conditions as a function of height were absent until recently (see discussion in Hofer et al., 2020).

Motivated by these observational gaps, we deployed a multiwavelength polarization Raman aerosol lidar at Dushanbe $\left(38.5^{\circ} \mathrm{N}, 68.8^{\circ} \mathrm{E}, 864 \mathrm{~m}\right.$ height above sea level, a.s.l.), Tajikistan, in the framework of the CADEX (Central Asian Dust EXperiment) project (Althausen et al., 2019). The lidar (Polly: POrtabLe Lidar sYstem) (Engelmann et al., 2016; Baars et al., 2016) was continuously operated over an 18-month period from March 2015 to August 2016. First re- 
sults were presented by Hofer et al. (2017). Profiles of basic aerosol optical properties and dust mass concentration in combination with vertically resolved dust source identification for representative aerosol scenarios were discussed based on case studies. Central Asia is in the middle of a large dust belt reaching from the western Sahara to the Gobi desert in China. Long-range transport of mineral dust from the deserts in the Middle East and from the Sahara, regional desert dust, local and regional anthropogenic haze and fire smoke, and background aerosol (mainly soil dust and salt dust from over 400 desiccating lakes in Central Asia and the Aralkum desert) lead to a complex aerosol mixture and complex vertical layering of aerosols in the planetary boundary layer and free troposphere, sometimes even up to heights close to the tropopause. A summary of the final results of this campaign in terms of aerosol height distributions, aerosol and dust optical thicknesses, height profiles of climate-relevant particle extinction coefficient at $532 \mathrm{~nm}$, mass concentrations and mass fractions of dust and nondust aerosol components, and aerosol parameters influencing cloud evolution and precipitation formation such as cloud condensation nucleus and ice-nucleating particle concentrations was presented by Hofer et al. (2020). More than 300 individual (day by day) nighttime observations were analyzed and cover well the annual cycle of dust and aerosol pollution layering conditions.

In this study, we focus on the main findings regarding those particle optical properties that are used in aerosoltyping efforts with lidar networks and spaceborne lidars. Observations of particle extinction-to-backscatter ratios (lidar ratios), linear depolarization ratios at 355 and $532 \mathrm{~nm}$ wavelength, and backscatter-related and extinction-related Ångström exponents (describing the wavelength dependence of backscatter and extinction coefficients from 355 to $1064 \mathrm{~nm}$ ), as presented here for Central Asian aerosol mixtures, are basic optical parameters in these aerosol-typing efforts and allow us to draw conclusions about the chemical composition (aerosol type), absorption and scattering properties, and size and shape characteristics of the particles (see, e.g., Müller et al., 2007; Burton et al., 2012, 2015; Groß et al., 2013; Nicolae et al., 2018; Papagiannopoulos et al., 2016, 2018; Voudouri et al., 2019). This article contributes to the steadily growing worldwide aerosol-typing database.

Lidar ratios and depolarization ratios measured with ground-based lidar systems around the globe are also required to guarantee a quality-assured data analysis of spaceborne lidar measurements. Global aerosol monitoring is currently performed with NASA's spaceborne lidar CALIOP (Cloud Aerosol Lidar with Orthogonal Polarization) (Winker et al., 2009; Winker et al., 2010; Omar et al., 2009) of the CALIPSO (Cloud-Aerosol Lidar and Infrared Pathfinder Satellite Observations) mission and with ALADIN (Atmospheric LAser Doppler INstrument) of the Aeolus mission of the European Space Agency (ESA) (Stoffelen et al., 2005; Ansmann et al., 2007; Flamant et al., 2008; Lux et al., 2020;
Witschas et al., 2020). In future, ATLID (Atmospheric Lidar) of the EarthCARE (Earth Clouds, Aerosols and Radiation Explorer) mission (Illingworth et al., 2015; Wandinger et al., 2016) will contribute to a 3D global characterization of aerosols. Lidar ratios and depolarization ratios are input parameters in space lidar data analyses operated at 532 and $1064 \mathrm{~nm}$ (CALIOP) and $355 \mathrm{~nm}$ (ALADIN, ATLID). Spectrally resolved lidar ratios and depolarization ratios, as presented here for Central Asian aerosol, are especially valuable with respect to the homogenization and harmonization of the overall 20-year CALIOP-ALADIN-ATLID aerosol climatology.

The article is structured as follows. In Sect. 2, we provide a brief overview of the CADEX campaign, the multiwavelength lidar, and observational products and uncertainties. Sections 3 and 4 contain the main findings and discussion regarding occurring aerosol types and origin of the aerosol particles forming the found aerosol mixtures. In Sect. 5, we discuss the potential impact of salt dust on the background aerosol optical properties. Concluding remarks are given in Sect. 6.

\section{CADEX lidar data analysis}

During the 18-month CADEX campaign from 17 March 2015 to 31 August 2016, a Polly-type multiwavelength polarization Raman lidar (Engelmann et al., 2016; Hofer et al., 2017, 2020) was operated in Dushanbe, Tajikistan. The Dushanbe lidar station is part of PollyNET, a network of permanent or campaign-based Polly lidar stations (Baars et al., 2016) and is the first outpost of the European Aerosol Research Lidar Network (EARLINET) (Pappalardo et al., 2014). The polarization Raman lidar permits us to measure height profiles of the particle backscatter coefficient $\beta$ at the laser wavelengths of 355,532 , and $1064 \mathrm{~nm}$, particle extinction coefficient $\alpha$ at 355 and $532 \mathrm{~nm}$ by means of 387 and $607 \mathrm{~nm}$ nitrogen Raman signal profiling, the particle linear depolarization ratio $\delta$ at 355 and $532 \mathrm{~nm}$ from the cross-polarized and total (co- and cross-polarized) lidar return signals at 355 and $532 \mathrm{~nm}$, and of the water-vapor-todry-air mixing ratio by using the Raman lidar return signals at $407 \mathrm{~nm}$ (water vapor channel) and of the $387 \mathrm{~nm}$ nitrogen Raman channel (e.g., Baars et al., 2016; Engelmann et al., 2016; Hofer et al., 2017; Dai et al., 2018). The Raman lidar method (Ansmann et al., 1992) was used to compute the particle backscatter coefficients not only at 355 and $532 \mathrm{~nm}$ but also at $1064 \mathrm{~nm}$. Here, the data analysis is based on the height profile of the ratio of the 1064 to $607 \mathrm{~nm}$ nitrogen Raman signal (Mattis et al., 2004). Particle extinction and transmission effects at 532, 607, and $1064 \mathrm{~nm}$ are corrected by means of the available extinction coefficient profiles at 355 and $532 \mathrm{~nm}$ and the respective wavelength dependence. The advantage of the Raman lidar method is that lidar ratios are not needed as 
input as is the case in the elastic-backscatter lidar retrieval (Fernald, 1984; Klett, 1985).

The particle linear depolarization ratio is defined as

$\delta=\frac{\beta_{\perp}}{\beta_{\|}}$.

A polarization lidar transmits linearly polarized laser pulses and detects the cross- and co-polarized signal components, or in the case of Polly the cross-polarized and total backscatter signals, from which the volume (particle + Rayleigh) linear depolarization ratio and the particle depolarization ratio as defined in Eq. (1) can be determined. The specific depolarization ratio retrieval in the case of the Polly instrument is described in detail by Engelmann et al. (2016). The depolarization ratio is an important parameter and allows us to unambiguously identify nonspherical dust particles and to quantify the dust mass fraction defined as the ratio of dust-to-totalparticle mass concentration (Hofer et al., 2020). The particle linear depolarization ratio is around 0.25 at $355 \mathrm{~nm}$ and 0.30 0.35 at $532 \mathrm{~nm}$ for coarse-mode-dominated size distributions of mineral dust particles. For small, spherical particles (finemode particles) the depolarization ratio is usually $<0.05$ at both wavelengths.

The multiwavelength Raman lidar option permits the independent determination of the particle backscatter and extinction coefficients (Ansmann et al., 1992) at 355 and $532 \mathrm{~nm}$ and, thus, the determination of the particle lidar ratio defined as

$S=\frac{\alpha}{\beta}$.

The lidar ratio depends on the size, shape, and absorption and scattering properties of the particles and can be as low as $15 \mathrm{sr}$ for marine sea salt particles and $>100 \mathrm{sr}$ for strongly absorbing black-carbon-containing smoke particles. The lidar ratio retrieval has the highest priority, and therefore we measure the total backscatter signal rather than the cross- and co-polarized backscatter signal components from which the total backscatter signal must then be constructed. By measuring the total lidar return signal we keep the uncertainties in the lidar ratio calculations as small as possible.

The measurement of the particle backscatter and extinction coefficients at several wavelengths $\lambda$ allows us to calculate the backscatter-related Ångström exponents $\dot{a}_{\beta, 355 / 532}$ and $\dot{a}_{\beta, 532 / 1064 \text {, }}$

$\dot{a}_{\beta, \lambda_{1} / \lambda_{2}}=\frac{\ln \left(\beta_{\lambda_{1}} / \beta_{\lambda_{2}}\right)}{\ln \left(\lambda_{2} / \lambda_{1}\right)}$,

and the extinction-related Ångström exponent $\dot{a}_{\alpha, 355 / 532}$,

$\dot{a}_{\alpha, \lambda_{1} / \lambda_{2}}=\frac{\ln \left(\alpha_{\lambda_{1}} / \alpha_{\lambda_{2}}\right)}{\ln \left(\lambda_{2} / \lambda_{1}\right)}$.

The Ångström exponent (Ångström, 1964) describes the spectral dependence of the optical properties and is strongly
Table 1. Particle optical properties observed with lidar during the CADEX campaign and typical values for the relative uncertainties in the presented layer mean values.

\begin{tabular}{ll}
\hline Parameter & Uncertainty \\
\hline Backscatter coefficient, $355 \mathrm{~nm}$ & $5 \%-10 \%$ \\
Backscatter coefficient, $532 \mathrm{~nm}$ & $5 \%-10 \%$ \\
Backscatter coefficient, $1064 \mathrm{~nm}$ & $10 \%-20 \%$ \\
Extinction coefficient, $355 \mathrm{~nm}$ & $10 \%-15 \%$ \\
Extinction coefficient, $532 \mathrm{~nm}$ & $10 \%-15 \%$ \\
Lidar ratio, $355 \mathrm{~nm}$ & $15 \%-20 \%$ \\
Lidar ratio, $532 \mathrm{~nm}$ & $15 \%-20 \%$ \\
Linear depolarization ratio, $355 \mathrm{~nm}$ & $5 \%$ \\
Linear depolarization ratio, $532 \mathrm{~nm}$ & $5 \%$ \\
Backscatter-related Ångström exponent (355-532 nm) & $10 \%$ \\
Backscatter-related Ångström exponent (532-1064 nm) & $20 \%$ \\
Extinction-related Ångström exponent (355-532 nm) & $10 \%-20 \%$ \\
\hline
\end{tabular}

influenced by the size of the particles. The values are large (1.5-2) for fine-mode-dominated aerosols such as urban haze or biomass burning smoke consisting of particles with radius mainly $<500 \mathrm{~nm}$ and is low $(0.5$ to -1$)$ for coarsemode-dominated particle size distributions (desert dust, sea salt aerosol). The backscatter and extinction Ångström exponents are linked via (Ansmann et al., 2002),

$\dot{a}_{\mathrm{S}}=\dot{a}_{\alpha}-\dot{a}_{\beta}$,

with the Ångström exponent $\dot{a}_{\mathrm{S}}$ for the lidar ratio. Table 1 provides an overview of the lidar products and typical retrieval uncertainties.

As outlined by Hofer et al. (2020), the polarization lidar allows us to separate the dust and non-dust-related backscatter, extinction, and (by using conversion factors) mass concentration contributions (Mamouri and Ansmann, 2017). The technique was recently updated with a focus on global desert dust sources (Ansmann et al., 2019). After separation, the dust mass fraction can be computed and used as an indicator for the aerosol mixing state (see Sect. 5).

\section{Observations}

During the 18-month CADEX campaign (535d), the Polly lidar acquired data at $487 \mathrm{~d}$ for at least a $3 \mathrm{~h}$ time period. To achieve a representative coverage of aerosol conditions, profiles were calculated on a day-by-day basis for each night at which the application of the Raman lidar methods was possible, i.e., when low clouds and fog were absent. The collected signal profiles were averaged over $60-180 \mathrm{~min}$ and smoothed with window lengths of typically $180-300 \mathrm{~m}$ (backscatter coefficients, depolarization ratios) and $750 \mathrm{~m}$ (extinction coefficients, lidar ratio). Raman lidar profiles of the particle extinction and backscatter coefficients and extinction-tobackscatter ratio (lidar ratio) at 355 and $532 \mathrm{~nm}$ could be obtained for 276 nights. In additional 52 nights, we could make use of the Raman lidar method to determine at least 

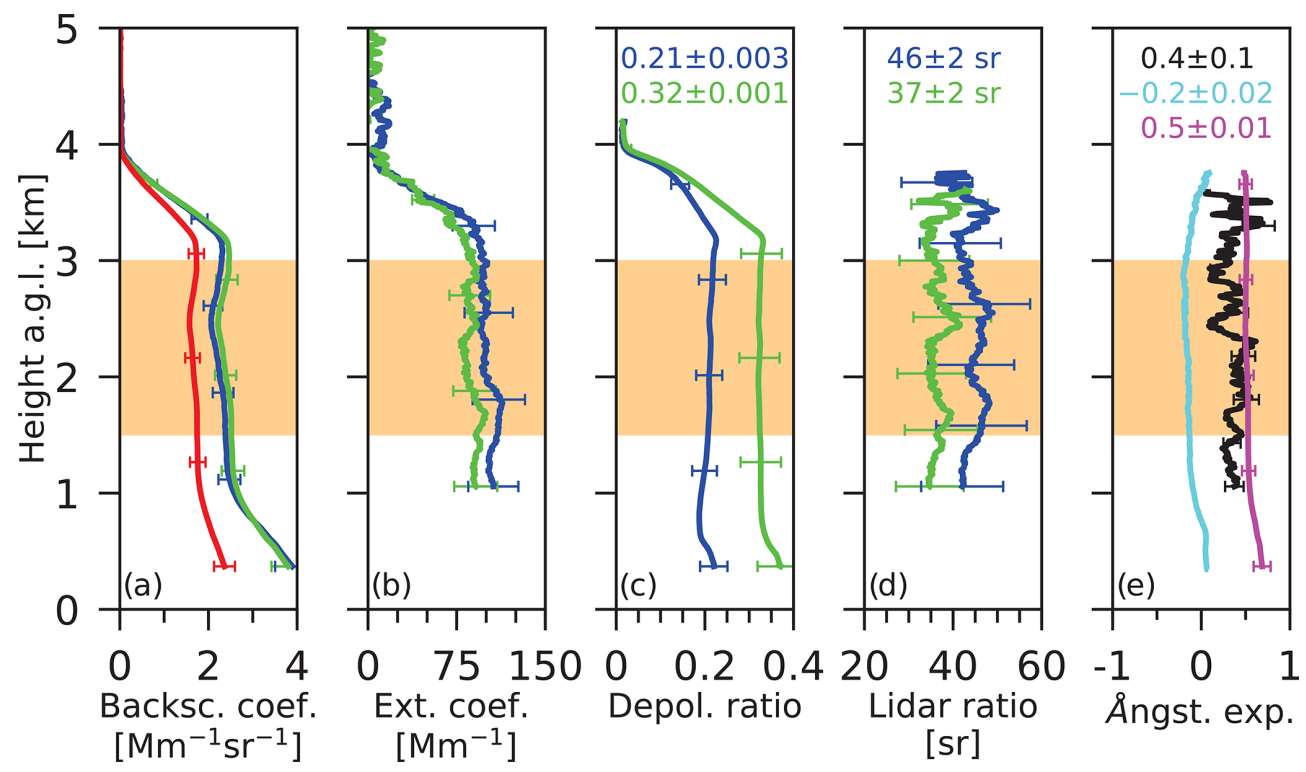

Figure 1. Profiles of optical properties measured on 11 June 2015, 18:00-20:59 UTC. (a) Particle backscatter coefficient at 355 (blue), $532 \mathrm{~nm}$ (green), and $1064 \mathrm{~nm}$ wavelength; (b) particle extinction coefficient at 355 (blue) and $532 \mathrm{~nm}$ (green); (c) particle linear depolarization ratio at 355 (blue) and $532 \mathrm{~nm}$ (green) wavelength; (d) lidar ratio at 355 (blue) and $532 \mathrm{~nm}$ (green) wavelength; (e) extinction-related Ångström exponent (black), backscatter-related Ångström exponent for the 355-532 (light blue), and 532-1064 nm (magenta) wavelength ranges. The horizontal orange area indicates the averaging height range from 1.5 to $3 \mathrm{~km}$ height. All profiles were calculated with the same $743 \mathrm{~m}$ vertical smoothing length. Numbers in (c), (d), and (e) show mean values for the orange layer and respective standard deviations. Error bars show the measurement uncertainties in the height profiles.

the backscatter coefficient profile. In these 52 cases, the atmospheric conditions were not favorable to derive extinction and lidar ratio profiles as well.

As shown in Hofer et al. (2020), we analyzed the annual cycle of aerosol layering in the lower, middle, and upper troposphere over Dushanbe based on these 328 aerosol backscatter profiles. By visual inspection we found two main regimes: (a) the main aerosol layer that typically extends from the surface to about $3-6 \mathrm{~km}$ height and contributes to $500 \mathrm{~nm}$ aerosol optical thickness (AOT) by usually more than $90 \%$ and (b) frequently occurring thin dust layers between 5 and $10 \mathrm{~km}$ height that mainly contained aerosol from remote source regions such as the Arabian deserts and Saharan desert. In this article, we concentrate on the mean optical properties in the main aerosol layer.

\subsection{Example of data analysis}

Figure 1 shows an example measurement to illustrate the procedure how we determined the layer-mean values. An averaging height range from 1.5 to $3 \mathrm{~km}$ height was chosen, and the layer mean optical properties were computed from the height profiles of the shown backscatter and extinction coefficients, depolarization ratios, lidar ratios, and Ångström exponents. The layer mean values were then used in the statistical analysis in Sect. 3.2 and in the correlation studies in Sect. 4.
Mineral dust dominated the optical properties on the 11 June 2015. Almost-wavelength-independent backscatter and extinction coefficients in the short-wavelength range $(355-532 \mathrm{~nm})$ were found as can be seen in Fig. 1a. The layer mean particle depolarization ratios were higher than $0.20(355 \mathrm{~nm})$ and $0.30(532 \mathrm{~nm})$, and the mean lidar ratios were around $46 \mathrm{sr}(355 \mathrm{~nm})$ and $37 \mathrm{sr}(532 \mathrm{~nm})$. All this indicates dusty condition on 11 June 2015.

\subsection{Statistical analysis}

Figures 2 and 3 provide an overview of the depolarization and lidar ratios observed during the 18 months from March 2015 to August 2016. The data are shown for the different seasons. Two spring and summer seasons and one autumn and winter seasons are covered. A broad distribution of depolarization ratios is found during the summer half-year (spring to autumn). The same holds for the lidar ratios. These broad distributions are indicative of the occurrence of very different aerosol conditions with complex aerosol mixtures of anthropogenic and natural aerosol types and components.

According to Rupakheti et al. (2019), the major air pollution sources in Central Asia include low-grade coal consumption in the households, industrial, construction, and mining activities, transportation facilities consisting of mostly old and poorly maintained vehicles, and natural sources such as agricultural activities and emissions from cropland, wildfires, deserts, and desiccating lakes and seas 


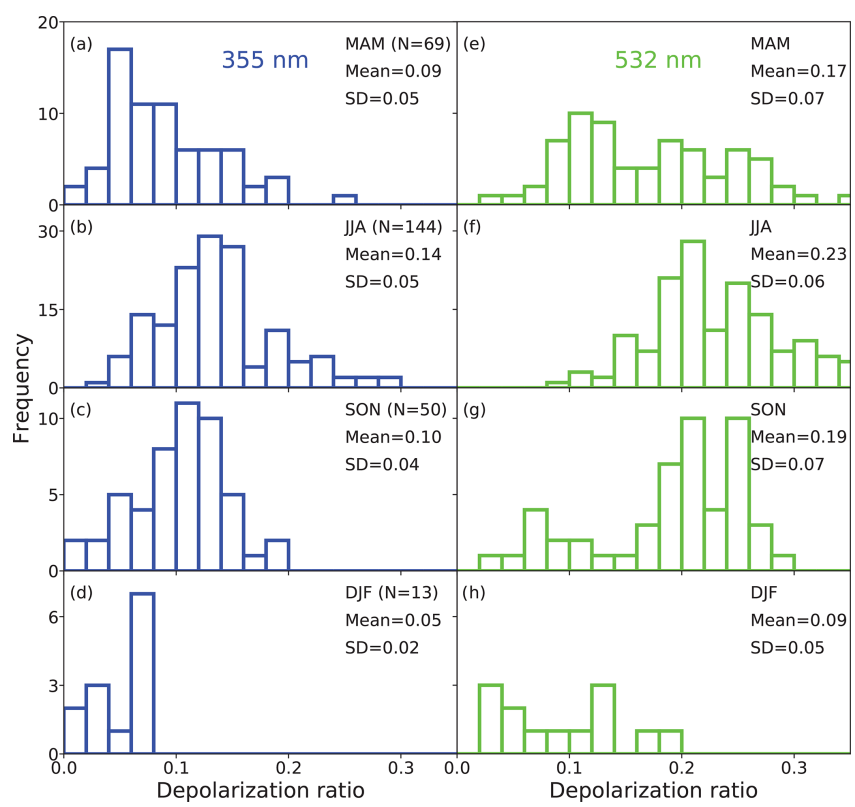

Figure 2. Histograms of layer-mean particle linear depolarization ratio at (a-d) $355 \mathrm{~nm}$ (blue) and (e-h) $532 \mathrm{~nm}$ wavelength (green) per season for (a, e) spring, (b, f) summer, (c, g) autumn, and (d, h) winter. (a-d) The number of observations per season is given in brackets. In addition, seasonal mean values and standard deviations are listed.

(e.g., Aral Sea). Tajikistan lies in the proximity of the deserts like Taklamakan, Aralkum, Kyzylkum, Karakum, and other deserts in Iran and Afghanistan. Desertification and the drying of the Aral Sea belong to the major environmental issues in Central Asia. Li and Sokolik (2017) estimated that the Aralkum desert contributes $12 \%$ to the Central Asian dust emissions. High aerosol loading during the spring and summer season is also favored by the low number of precipitation events. In addition to all the local and regional aerosol sources, long-range transport of dust and pollution contributes to the complexity of the observed aerosol mixtures (Hofer et al., 2020).

As can be seen in Fig. 2, the depolarization ratio ranged from values for pure urban haze conditions $(0.0$ to 0.03$)$ to values typical for heavy dust outbreak conditions (up to 0.3 at $355 \mathrm{~nm}$ and up to 0.35 at $532 \mathrm{~nm}$ ). Lidar ratios from 25 to $65 \mathrm{sr}$ were found, accumulating around $30-45 \mathrm{sr}(355 \mathrm{~nm}$, mean of $42 \mathrm{sr})$ and $25-35 \mathrm{sr}(532 \mathrm{~nm}$, mean of $33 \mathrm{sr}-$ see Fig. 3). In the summer half-year, long-range transport of dust from southwesterly directions prevail (Hofer et al., 2020). In addition, local and regional dust contribute. The influence of anthropogenic pollution (industry, traffic) is low. Only during the winter months (heating season), urban haze dominates in Dushanbe. In winter, the impact of long-range transport of dust is strongly reduced because of low convective activity and, thus, obviously also emissions over the desert areas.

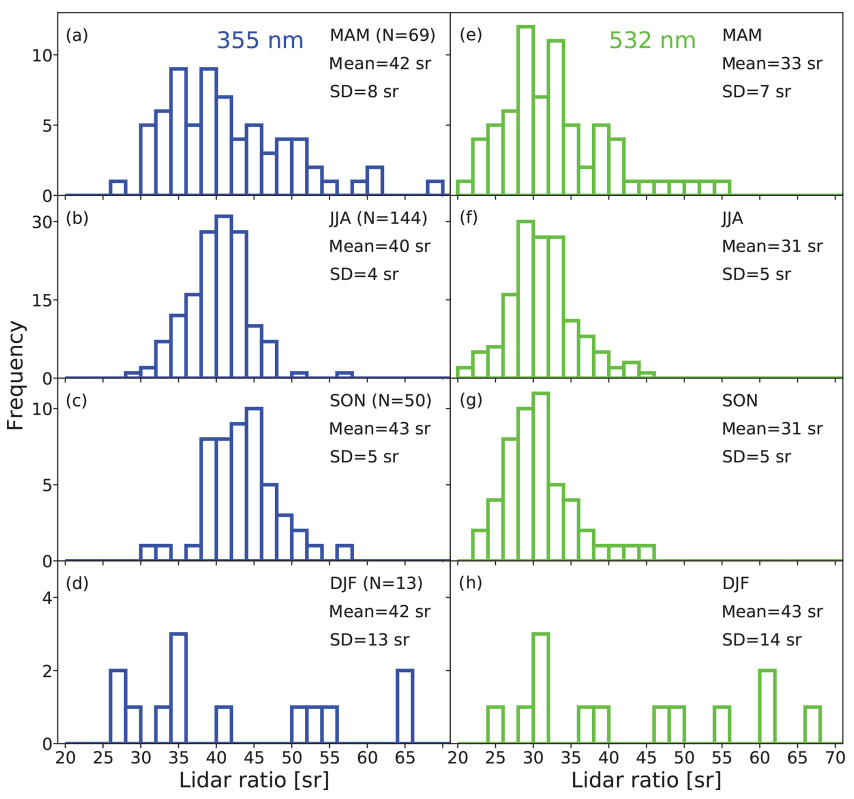

Figure 3. Same as Fig. 2, except for the lidar ratios at 355 and $532 \mathrm{~nm}$.

The comparably low lidar ratios reflect the frequent occurrence of dust from Middle Eastern and Central Asian desert regions. Lidar ratios for these dust particles are much lower (Mamouri et al., 2013; Nisantzi et al., 2015; Hofer et al., 2017; Filioglou et al., 2020) than the ones for central and western Saharan regions, which are typically in the range of 40-65 sr (Mattis et al., 2002; Mona et al., 2006; GuerreroRascado et al., 2009; Giannakaki et al., 2010; Groß et al., 2011; Tesche et al., 2011; Kanitz et al., 2013; Preißler et al., 2013; Guerrero-Rascado et al., 2009; Veselovskii et al., 2016; Rittmeister et al., 2017; Bohlmann et al., 2018).

Figure 4 shows histograms of extinction-related Ångström exponents for the different seasons of the year. Again, a broad distribution of values from around 0 (pure dust) to 2.4 (fresh urban haze and smoke) are found. However, the seasonal mean values for the Ångström exponent (355-532 nm spectral range) are all at around $1.1 \pm 0.5$.

Figure 5 summarizes the statistical analysis and provides insight into the annual cycle of the different optical properties found in the lower troposphere (see layer height information in Fig. 5d). Seasonal mean values, standard deviation, and range of values for the derived lidar ratios, depolarization ratios, and Ångström exponents are given in Tables 2 to 4.

Table 2 contrasts dust and non-dust optical properties. The criterion used for pure dust is $\delta>0.31$ at $532 \mathrm{~nm}$ and is $\delta<0.05$ for (non-dust) anthropogenic pollution cases. The mean values of the dust lidar ratios and depolarization ratios in Table 2 are very close to the values recently presented by Filioglou et al. (2020) for Middle Eastern desert dust, measured in the Emirate of Sharjah during a 1-year campaign. 


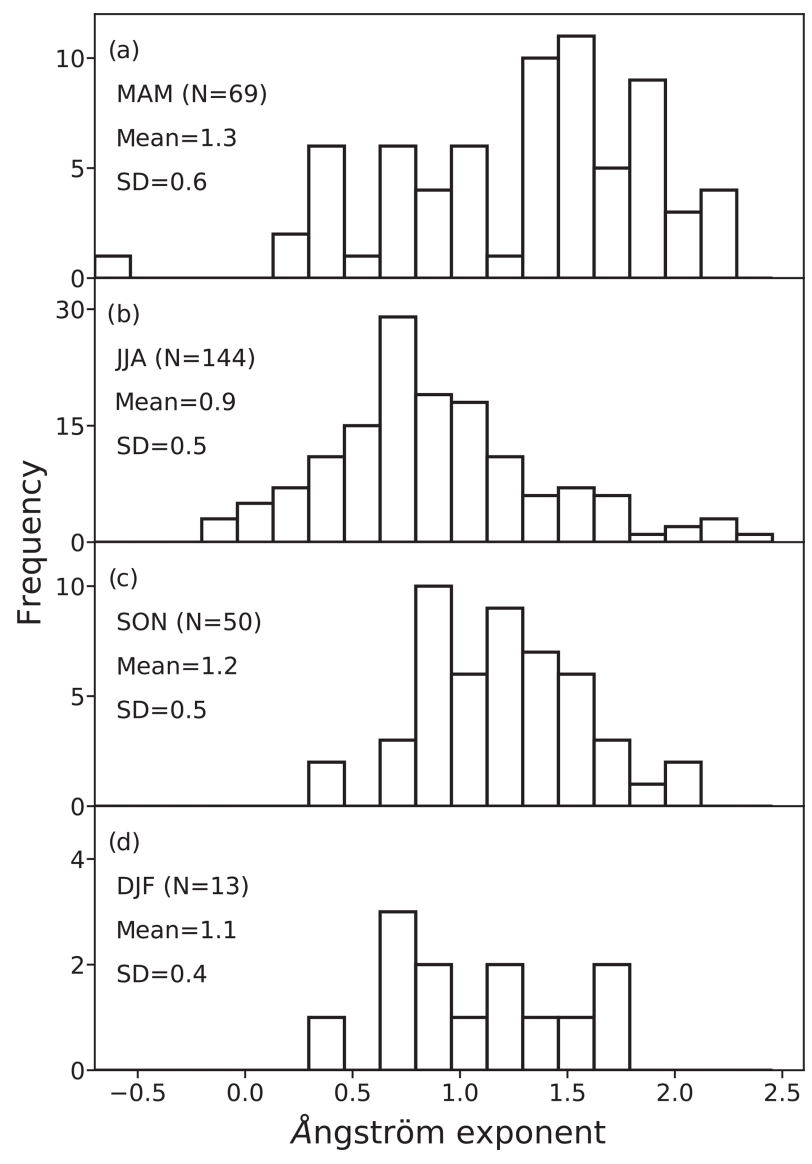

Figure 4. Same as Fig. 2, except for the extinction-related Ångström exponent $\dot{a}_{\alpha, 355 / 532}$.

Table 3 summarizes seasonal mean values, standard deviations, and range of values for the lidar ratios and depolarization ratios at both wavelengths. The seasonal mean lidar ratio at $355 \mathrm{~nm}$ does not vary much from season to season, in contrast to the seasonal mean lidar ratio at $532 \mathrm{~nm}$. During the summer half-year, the seasonal mean values are 31$33 \mathrm{sr}$ at $532 \mathrm{~nm}$ and thus even lower than the pure dust-related value of $39 \mathrm{sr}$ in Table 2 . When anthropogenic particles dominate (in winter), the mean value was found to be $43 \mathrm{sr}$ at $532 \mathrm{~nm}$ (and, thus, close to the value at $355 \mathrm{~nm}$ ). These hazerelated values are again lower than the respective pure pollution values in Table 2 and, thus, point also to the presumption of a background aerosol causing a very low lidar ratio at $532 \mathrm{~nm}$. This aspect is further discussed in Sect. 5. The contrast between summer and winter depolarization values in Table 3 reflects the change from dust-dominated to pollutiondominated aerosol conditions as well.

Table 4 summarizes the findings concerning the backscatter- and extinction-related Ångström exponents. In the case of strong dust outbreaks with a large coarse-dust fraction, the Ångström exponents for the $355-532 \mathrm{~nm}$ spectral range are partly negative. Similar results are reported

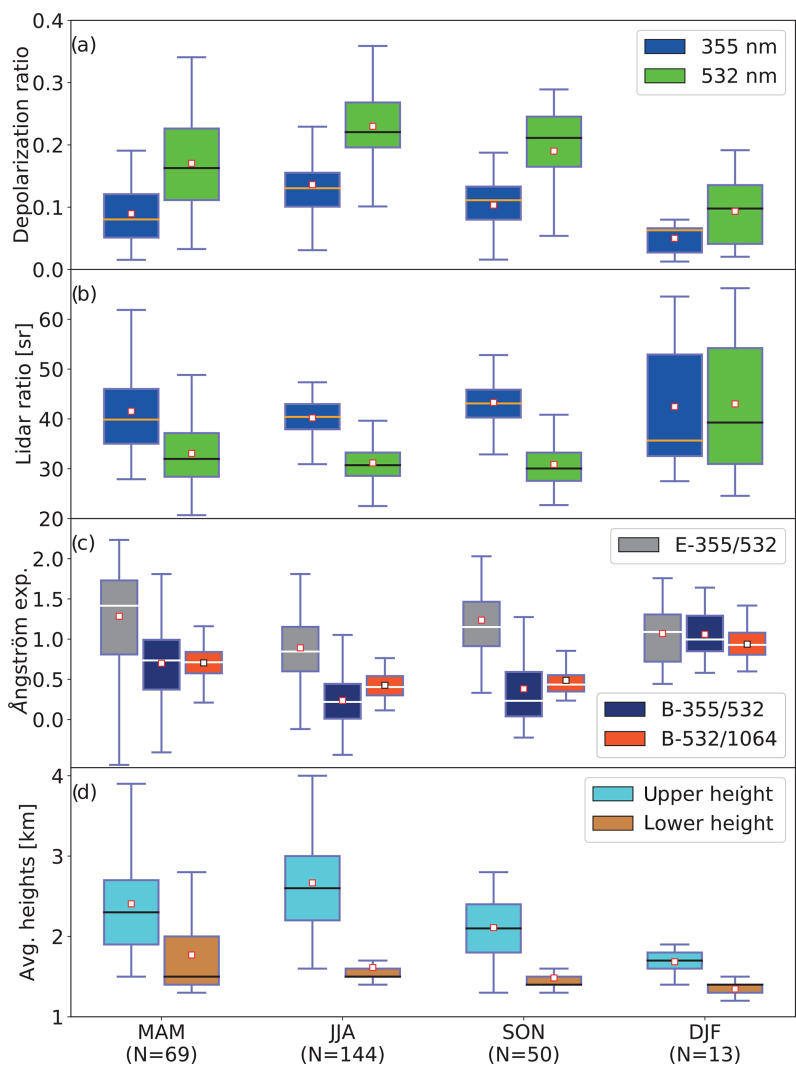

Figure 5. Boxplots of layer-mean (a) particle linear depolarization ratio and (b) lidar ratio at 355 and $532 \mathrm{~nm}$ wavelength, (c) of extinction-related (E-355/532) and backscatter-related (B355/532, B-532/1064) Ångström exponents, and (d) of lower and upper boundaries of the respective signal averaging layers for which the optical properties are computed. The statistical results are given for spring (MAM), summer (JJA), autumn (SON), and winter (DJF) with number of observations in brackets. The box indicates the interquartile range (IQR), in which $50 \%$ of the data accumulate. Seventy-five percent of the data points are within the range indicated by the whiskers (1.5 IQR). Seasonal mean and median values are given as open squares and horizontal lines, respectively.

for Saharan dust when the observations were conducted within or close to the dust source region (Kanitz et al., 2013; Veselovskii et al., 2016; Rittmeister et al., 2017).

The observations at Dushanbe fit well into the general picture of lidar-derived particle optical properties for northern hemispheric aerosol mixtures. Overviews of lidar ratios and depolarization ratio for a variety of different aerosol types are given by, e.g., Müller et al. (2007) and Nicolae et al. (2018). We checked the literature especially with a focus on dust-related optical properties. The numerous lidar observations of depolarization ratios around the world indicate quite uniform light depolarization characteristics for mineral dust. An overview is given by Shin et al. (2018). Maximum values of particle linear polarization ratios are 0.23 0.30 at $355 \mathrm{~nm}$ and $0.3-0.35$ at $532 \mathrm{~nm}$ (e.g., Sugimoto and 
Table 2. Mean values \pm SD of pure dust and non-dust lidar ratios $\left(S_{355}, S_{532}\right)$, particle linear depolarization ratios $\left(\delta_{355}, \delta_{532}\right)$ at 355 and $532 \mathrm{~nm}$ wavelength and extinction-related Ångström exponent $\left(\dot{a}_{\alpha, 355 / 532}\right) . N$ is the number of cases.

\begin{tabular}{lrrrrrr}
\hline Type & $N$ & $S_{355}(\mathrm{sr})$ & $S_{532}(\mathrm{sr})$ & $\delta_{355}$ & $\delta_{532}$ & $\dot{a}_{\alpha, 355 / 532}$ \\
\hline Dust & 17 & $43 \pm 3$ & $39 \pm 4$ & $0.24 \pm 0.03$ & $0.33 \pm 0.01$ & $0.1 \pm 0.2$ \\
Non-dust & 7 & $50 \pm 10$ & $51 \pm 10$ & $0.02 \pm 0.01$ & $0.03 \pm 0.01$ & $1.5 \pm 0.3$ \\
\hline
\end{tabular}

Table 3. Seasonal mean(median) values \pm SD of lidar ratios $\left(S_{355}, S_{532}\right)$ and particle linear depolarization ratio $\left(\delta_{355}, \delta_{532}\right)$ at 355 and $532 \mathrm{~nm}$ wavelength. The range of the values from minimum to maximum is given in the second row.

\begin{tabular}{lrrrr}
\hline Season & $S_{355}(\mathrm{sr})$ & $S_{532}(\mathrm{sr})$ & $\delta_{355}$ & $\delta_{532}$ \\
\hline MAM & $42(40) \pm 8$ & $33(32) \pm 7$ & $0.09(0.08) \pm 0.05$ & $0.17(0.16) \pm 0.07$ \\
& $28-69$ & $21-56$ & $0.02-0.26$ & $0.03-0.34$ \\
\hline JJA & $40(40) \pm 4$ & $31(31) \pm 5$ & $0.14(0.13) \pm 0.05$ & $0.23(0.22) \pm 0.06$ \\
& $28-57$ & $19-44$ & $0.03-0.29$ & $0.08-0.36$ \\
\hline SON & $43(43) \pm 5$ & $31(30) \pm 5$ & $0.10(0.11) \pm 0.04$ & $0.19(0.21) \pm 0.07$ \\
& $30-56$ & $23-46$ & $0.02-0.19$ & $0.02-0.29$ \\
\hline DJF & $42(36) \pm 13$ & $43(39) \pm 14$ & $0.05(0.06) \pm 0.02$ & $0.09(0.10) \pm 0.05$ \\
& $28-65$ & $25-66$ & $0.01-0.08$ & $0.02-0.19$ \\
\hline
\end{tabular}

Table 4. Seasonal mean(median) values \pm SD of backscatter-related $\left(\dot{a}_{\beta, 355 / 532}, \quad \dot{a}_{\beta, 532 / 1064}\right)$ and extinction-related $\left(\dot{a}_{\alpha, 355 / 532}\right)$ Ångström exponents. The range of the values from minimum to maximum is given in the second row.

\begin{tabular}{lrrr}
\hline Season & $\dot{a}_{\alpha, 355 / 532}$ & $\dot{a}_{\beta, 355 / 532}$ & $\dot{a}_{\beta, 532 / 1064}$ \\
\hline MAM & $1.3(1.4) \pm 0.6$ & $0.7(0.7) \pm 0.5$ & $0.7(0.7) \pm 0.2$ \\
& $-0.6-2.2$ & $-0.4-1.8$ & $0.1-1.4$ \\
\hline JJA & $0.9(0.8) \pm 0.5$ & $0.2(0.2) \pm 0.3$ & $0.4(0.4) \pm 0.2$ \\
& $-0.1-2.4$ & $-0.4-1.2$ & $0.1-1.1$ \\
\hline SON & $1.2(1.2) \pm 0.5$ & $0.4(0.2) \pm 0.5$ & $0.5(0.4) \pm 0.2$ \\
& $0.3-3.3$ & $-0.2-1.8$ & $0.2-1.1$ \\
\hline DJF & $1.1(1.1) \pm 0.4$ & $1.1(1.0) \pm 0.3$ & $0.9(0.9) \pm 0.3$ \\
& $0.4-1.8$ & $0.6-1.6$ & $0.2-1.4$ \\
\hline
\end{tabular}

Lee, 2006; Freudenthaler et al., 2009; Burton et al., 2015; Veselovskii et al., 2016; Hofer et al., 2017; Hu et al., 2020; Filioglou et al., 2020). Sun-photometer-based studies corroborate our impression that light depolarization by dust is not a function of the dust source and does not vary much around the globe (Shin et al., 2018). Since the depolarization ratio is strongly influenced by particle shape and size distribution characteristics, we may conclude that natural mineral dust particle ensembles show rather similar size and shape properties disregarding the region where the dust particles were released into the atmosphere. The same conclusions were drawn by Ansmann et al. (2019).

However, a certain variability in the depolarization ratio characteristics must be always kept in consideration because of changes in the dust size distribution during long-range transport related to a stronger removal of coarse and giant particles from the atmosphere than the deposition of finemode dust particles. It was shown that the fine-mode dust fraction (particles with radius $<500 \mathrm{~nm}$ ) contributes about $20 \%$ to the overall dust AOT at 355 and $532 \mathrm{~nm}$ (Mamouri and Ansmann, 2014, 2017). We concluded from our combined photometer-lidar observations that the same fine-mode impact holds for the backscatter coefficients and depolarization ratios. The fine-mode-related dust depolarization ratio is roughly $0.20,0.15$, and 0.10 for 355,532 , and $1064 \mathrm{~nm}$ wavelength, respectively. The coarse-mode causes depolarization ratios of around $0.25-0.30(355 \mathrm{~nm}), 0.35-0.40(532 \mathrm{~nm})$, and $0.25-0.30(1064 \mathrm{~nm})$, as lidar observations of long-range transport of dust together with the laboratory studies indicate (Haarig et al., 2017a; Mamouri and Ansmann, 2017). This has to be taken into account in the comparison of the findings discussed in Sect. 4 and explains small changes in the dust depolarization ratios downwind the dust sources as found by Haarig et al. (2017a) and Rittmeister et al. (2017).

In contrast to these small depolarization ratio changes, the extinction-to-backscatter ratio varies considerably from dust source to dust source as a result of changing dust mixtures and thus changing chemical compositions. Latest overviews of measured dust lidar ratios are given by Nicolae et al. (2018), Shin et al. (2018), and Kim et al. (2020). Sakai et al. (2002) and Liu et al. (2002) for Asian dust and Mattis et al. (2002) for Saharan dust were the first to demonstrate that the dust lidar ratio is not close to $20 \mathrm{sr}$ (as modeled for spherical dust particles) but in the range of 40-50 sr $(532 \mathrm{~nm}$, Asian dust) and 50-70 sr (355 and $532 \mathrm{~nm}$, Saharan dust) because 


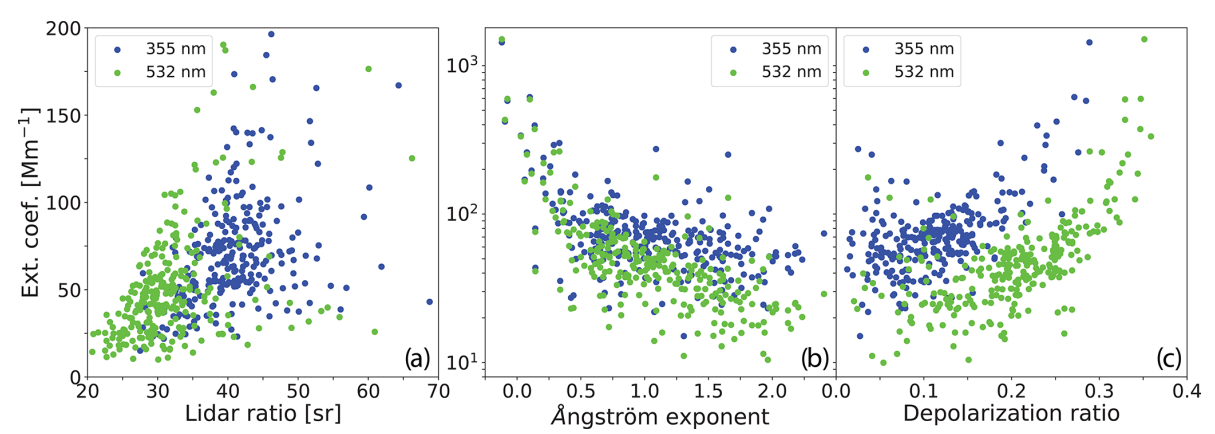

Figure 6. Correlation between the particle extinction coefficient at 355 and $532 \mathrm{~nm}$ and (a) the 355 and $532 \mathrm{~nm}$ particle lidar ratios, (b) the extinction-related Angström exponent (355-532 nm spectral range; blue and green show the same data set on the $x$ axis), and (c) 355 and $532 \mathrm{~nm}$ particle linear depolarization ratios. All individual nighttime observations of the 1.5-year campaign are considered.

of the irregular shape of the dust particles. Mamouri et al. (2013) then emphasized that Middle Eastern dust can cause a quite low lidar ratio of 34-39 sr (532 nm) and that this contrast to Saharan dust is probably related to the difference in mineralogical composition. The low lidar ratios were also observed by Nisantzi et al. (2015) and Hofer et al. (2017).

Veselovskii et al. (2020) relate variations in the ratio of Saharan dust lidar ratios at 355 and $532 \mathrm{~nm}$ wavelength to the dust source region mineralogy. The ratio of the lidar ratios can be an indicator of an increased imaginary part of the complex refractive index in the UV. This could enable discrimination between different dust types of similar large depolarization ratios of $>0.3$ based on the ratio of the lidar ratios.

Shin et al. (2018) discussed the chemical composition of Saharan, Middle Eastern, Asian, and Australian dust and the link to the characteristic lidar ratios. The authors state that Saharan dust contains a comparably high amount of clay minerals (e.g., kaolinite, illite, montmorillonite) which absorbs light at solar wavelengths. The imaginary part of the refractive index increases towards shorter wavelengths. That could explain the relatively high Saharan dust lidar ratios. Varying contents of iron oxide minerals (e.g., hematite), which also strongly absorb in the UV and at visible wavelengths, and varying amounts of calcite and gypsum, which show almost no absorption in the UV and at visible wavelengths, modulate the observed lidar ratio variations. According to Shin et al. (2018), lower portions of clay in the mineral compositions in eastern Asian and Middle Eastern dust lead to lower lidar ratios (35-45 sr) compared to Saharan dust lidar ratios. Quartz has strong absorption bands in the infrared, while its absorption properties are negligible at UV and visible wavelengths. Dust from Australian deserts consists mostly of quartz, and thus the lidar ratios are in the range of 30-35 sr, $532 \mathrm{~nm}$ (Shin et al., 2018). All this is in consistency with the global lidar ratio study recently presented by Kim et al. (2020).

\section{Correlation studies}

In this section, we illuminate the relationship between the different lidar-derived aerosol optical properties to provide further insight into the aerosol mixing states and characteristics. The discussion is complementary to the findings presented by Hofer et al. (2020) and can be regarded as a contribution to the aerosol typing and classification efforts.

Figure 6 shows the basic correlation between the particle extinction coefficients at 355 and $532 \mathrm{~nm}$ and the respective 355 and $532 \mathrm{~nm}$ lidar ratios and depolarization ratios. In addition, the correlations between the extinction-related Ångström exponent (for the $355-532 \mathrm{~nm}$ wavelength range) and the extinction coefficient at $355 \mathrm{~nm}$ (in blue) and at $532 \mathrm{~nm}$ (in green) is shown. The shifts between the blue and green data sets are partly caused by the different extinction coefficients. On average, the $355 \mathrm{~nm}$ extinction coefficients are roughly a factor of 1.5 larger than the $532 \mathrm{~nm}$ extinction coefficients as a result of the impact of non-dust aerosol (mainly fine-mode particles) leading to a mean Ångström exponent of around 1 (see Fig. 4).

As can be seen in Fig. 6, the lidar ratio and depolarization ratio increase with increasing dust impact, indicated by an increasing extinction coefficient, whereas the Ångström exponent decreases and shows a broad spectrum from 0.5 to 2.2 for $532 \mathrm{~nm}$ extinction values $<100 \mathrm{Mm}^{-1}$. There is a clear shift in the lidar ratio and depolarization ratio data sets $(355 \mathrm{~nm}$ vs. $532 \mathrm{~nm})$. In full agreement with many other studies (e.g. Groß et al., 2011; Haarig et al., 2017a), the $355 \mathrm{~nm}$ depolarization ratios are lower by about 0.1 disregarding the mixing state, mainly as the result of the generally stronger impact of fine-mode particles on the $355 \mathrm{~nm}$ optical properties. The lidar ratios are larger at $355 \mathrm{~nm}$ because of the stronger impact of fine-mode aerosol pollution on the $355 \mathrm{~nm}$ extinction coefficient and the usually higher absorption of radiation. The lidar ratios are on average about $10 \mathrm{sr}$ larger at $355 \mathrm{~nm}$ than at $532 \mathrm{~nm}$.

For low extinction coefficients, the optical properties of the background aerosol become visible. At low overall parti- 


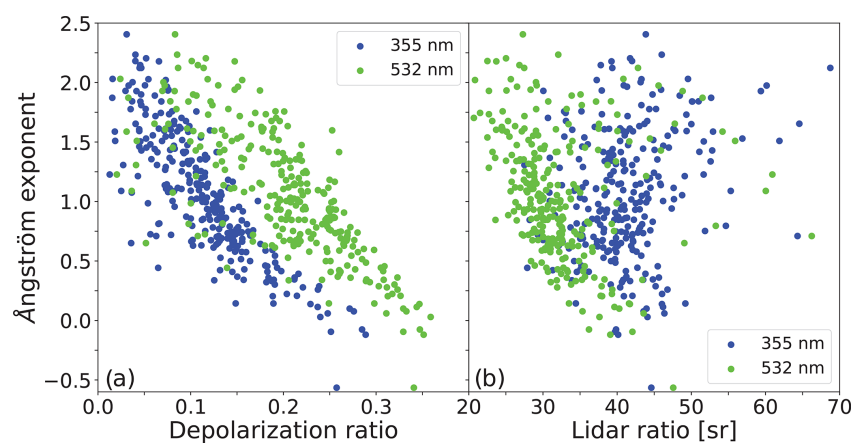

Figure 7. Correlation between the extinction-related Ångström exponent (355-532 nm) and (a) the 355 and $532 \mathrm{~nm}$ particle linear depolarization ratios and (b) the 355 and $532 \mathrm{~nm}$ particle lidar ratios.

cle extinction levels, neither dust outbreak nor local pollution conditions dominate. With decreasing particle extinction coefficient the $532 \mathrm{~nm}$ lidar ratio decreases towards $20 \mathrm{sr}$. The lidar ratio for $355 \mathrm{~nm}$ is higher because it is still influenced by residual haze in the background aerosol mixtures. For low extinction values, the noise (uncertainty) in the determined Ångström exponents becomes dominant so that clear conclusions regarding background Ångström values cannot be drawn. However, a broad distribution from 0.5 to 2.0 is visible for low $532 \mathrm{~nm}$ extinction values $\left(<25 \mathrm{Mm}^{-1}\right)$. The depolarization ratios do not show a clear picture but suggest that the background aerosol still contains a fraction of nonspherical particles. The $532 \mathrm{~nm}$ lidar ratios and depolarization ratios for background extinction levels may thus point to an increasing impact of dry salt particles to the light extinction (Haarig et al., 2017b) as discussed in Sect. 5.

In Fig. 7, the correlation between the extinction-related Ångström exponent and the 355 and $532 \mathrm{~nm}$ lidar ratios and depolarization ratios are shown. An increasing Ångström exponent indicates an increasing fraction of anthropogenic haze and biomass burning smoke in the aerosol mixture. A well-defined relationship is found for the depolarization ratios. With decreasing Ångström exponent (and increasing influence of dust), the depolarization ratios increase and show maximum values of $0.25-0.3(355 \mathrm{~nm})$ and around 0.35 $(532 \mathrm{~nm})$. The correlation is less clear for the lidar ratio. The $355 \mathrm{~nm}$ extinction-to-backscatter ratio is always around $40 \mathrm{sr}$ at $355 \mathrm{~nm}$ disregarding whether pollution or dust dominates. Also at $532 \mathrm{~nm}$, the correlation is weak.

The impact of the given aerosol mixture on the lidar ratio is further illuminated in Fig. 8. Here, the depolarization ratio is plotted vs. the lidar ratio. The individual (color-coded) measurements are sorted by dust mass fraction as well. As introduced in Sect. 2, the dust mass fraction describes the relative contribution of dust to the overall particle mass concentration. For dust fractions around 1 and depolarization ratios $>0.2(355 \mathrm{~nm})$ and $>0.3(532 \mathrm{~nm})$, the respective dust lidar ratios accumulate in the range of $40-45 \mathrm{sr}(355 \mathrm{~nm})$ and 30

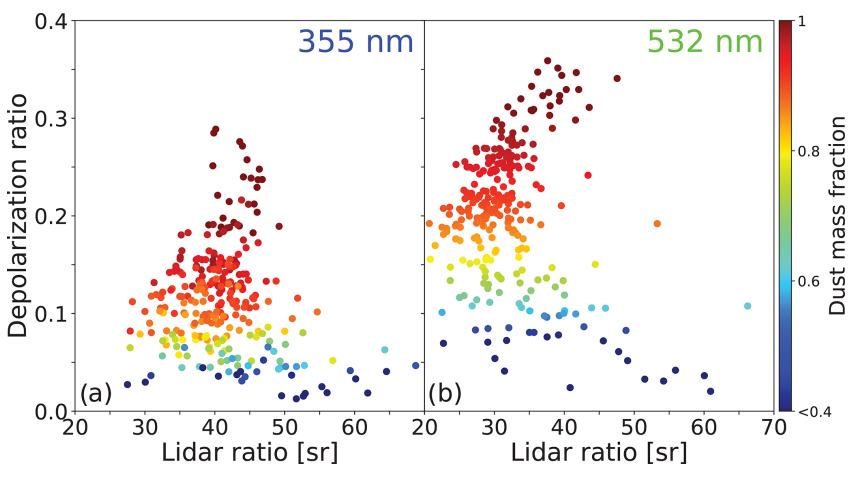

Figure 8. Correlation between (a) the $355 \mathrm{~nm}$ particle linear depolarization ratio and the $355 \mathrm{~nm}$ particle lidar ratio and (b) the $532 \mathrm{~nm}$ particle linear depolarization ratio and the $532 \mathrm{~nm}$ particle lidar ratio. The depolarization and lidar ratios are color-coded as a function of dust mass fraction.

$40 \mathrm{sr}(532 \mathrm{~nm})$. In contrast, for low depolarization ratios and comparably low dust fractions, a large spread in the lidar ratio values is found (from 25 to $70 \mathrm{sr}$ at $355 \mathrm{~nm}$ and 20 to $60 \mathrm{sr}$ at $532 \mathrm{~nm}$ ). Note that the particle extinction coefficient for a given particle mass concentration is about a factor of 5 higher in the case of anthropogenic particles compared to dust particles. Thus, the dust mass fractions of 0.5 correspond roughly to a dust fraction of 0.1 in terms of dust and pollution extinction coefficients. Note also that for low $532 \mathrm{~nm}$ lidar ratios $(<30 \mathrm{sr}$, frequently found during aerosol background condition), many depolarization values are considerably higher than 0.1 and indicate the presence of a considerable fraction of nonspherical particles.

The curved feature in Fig. 8b with higher lidar ratios for small and large $532 \mathrm{~nm}$ depolarization ratios is in principle also found for $355 \mathrm{~nm}$; however the range of observed depolarization ratio is smaller so that the curved feature is compressed and a clear minimum of the $355 \mathrm{~nm}$ lidar ratio for moderate depolarization ratios around 0.1 is not visible. Furthermore, the optical properties at $355 \mathrm{~nm}$ are dominated by scattering and absorption by fine-mode aerosol (especially by anthropogenic haze) and are less influenced by scattering by coarse-mode (desert or salt) dust particles than the ones for the $532 \mathrm{~nm}$ wavelength. Thus, the background aerosol effect shows up more pronounced for $532 \mathrm{~nm}$.

Figure 9 provides insight into the spectral dependence of the particle extinction coefficient vs. the spectral dependencies of the depolarization ratio and lidar ratio. Again, the individual observations are color-coded according to the different dust mass fraction levels. Such a correlation is helpful in the discussion of data harmonization efforts when one spaceborne lidar data set is collected at $355 \mathrm{~nm}$ (ALADIN, ATLID) and the other data set at $532 \mathrm{~nm}$. As can be seen, there is a weak correlation between the Ångström exponent and the ratios of depolarization and lidar ratios. For low values of the Ångström exponent (and high values of the dust mass 


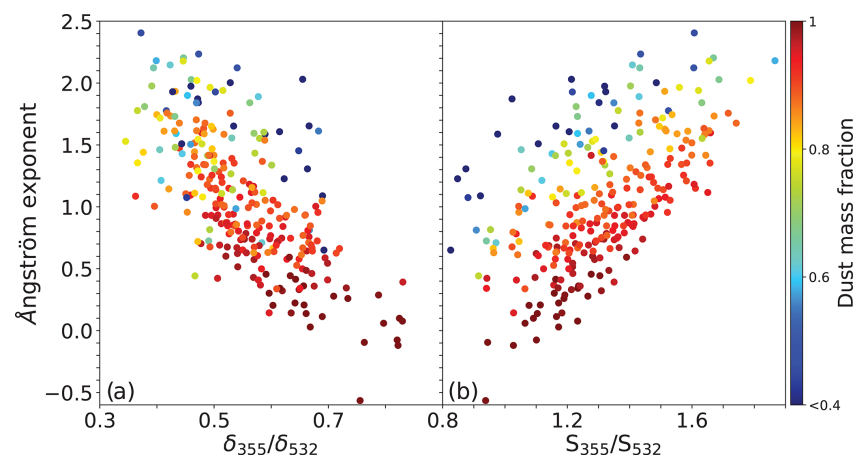

Figure 9. Correlation between the extinction-related Ångström exponent and (a) the ratio of depolarization ratios and (b) the ratio of lidar ratios at 355 and $532 \mathrm{~nm}$ wavelength. The values are colorcoded as a function of dust mass fraction.

fraction), the ratios $\delta_{355} / \delta_{532}$ and $S_{355} / S_{532}$ are approaching the pure dust values of around 0.75 and $1-1.2$, respectively, whereas for Ångström exponents indicating dominating anthropogenic haze conditions, the depolarization and lidar ratios are very variable and accumulate at $0.4-0.6$ and $1.2-1.7$, respectively.

To complete the discussion on the correlations between the lidar-derived optical properties, Fig. 10 shows a correlation of dust extinction coefficient (in contrast to Fig. 6 now only for $532 \mathrm{~nm}$ ) and the backscatter-related Ångström exponents for the two wavelength ranges from 355 to 532 and 532 to $1064 \mathrm{~nm}$. Mean values, standard deviations, and range of values are given in Table 4. For large extinction coefficients and thus a strong dust impact, we frequently found negative $355-532 \mathrm{~nm}$ backscatter-related Ångström exponents. This is a unique feature of dust, probably related to strong dust outbreaks (and dust observations close to the dust source region) with a pronounced coarse-mode dust fraction and the presence of even some giant particles (with diameters $>20 \mu \mathrm{m}$ ). This feature was also observed, e.g., by Bohlmann et al. (2018) and Rittmeister et al. (2017) and especially emphasized by Veselovskii et al. (2016). The range of observed values is larger ( -0.5 to 1.8$)$ for the $355-$ $532 \mathrm{~nm}$ backscatter-related Ångström exponents compared to the 532-1064 nm backscatter-related Ångström exponent (0.1 to 1.4). This corresponds to the different sensitivities of the three wavelengths to fine-mode particles, and large and very large (or giant) coarse-mode particles (Mamouri and Ansmann, 2017; Haarig et al., 2017a). The likewise small range of 532-1064 nm backscatter-related Ångström exponents indicate that in most cases, however, very large or giant dust particles were absent over Dushanbe, removed during the long-range transport of dust.

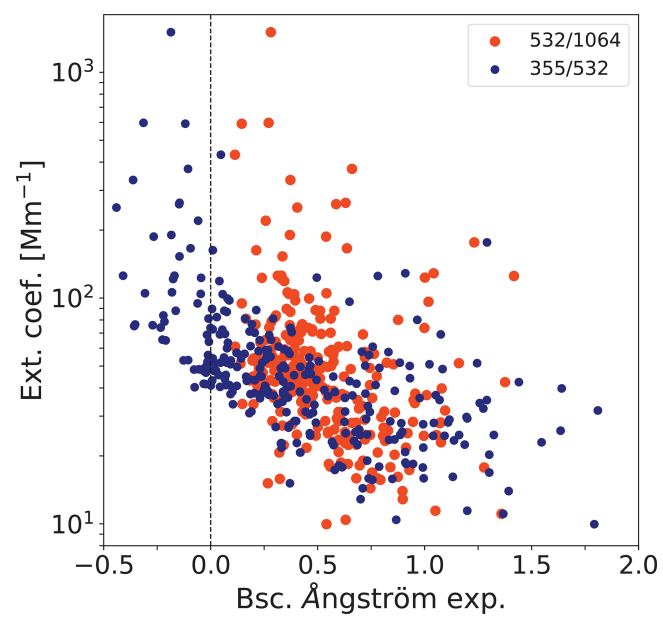

Figure 10. Correlation between the backscatter-related Ångström exponents (blue: $355-532 \mathrm{~nm}$ spectral range; red: 532-1064 nm spectral range) and the $532 \mathrm{~nm}$ particle extinction coefficient.

\section{Background aerosol: the potential impact of salt dust}

On 45 d ( $15 \%$ out of the 276 cases of daily nighttime aerosol Raman lidar measurements), we found aerosol layers in the lower troposphere that showed a rather low particle extinction coefficient at $532 \mathrm{~nm}\left(<30 \mathrm{Mm}^{-1}\right)$ together with an enhanced particle depolarization ratio of $10 \%-20 \%$ and a lidar ratio of $25 \mathrm{sr}$ and less. An example is shown in Fig. 11. Local and regional pollution influenced the optical properties below $1.5-1.6 \mathrm{~km}$ height. However, above $1.6 \mathrm{~km}$ a relatively clean layer with background aerosol and particle extinction coefficients around $20 \mathrm{Mm}^{-1}$ was observed.

The corresponding backward trajectories for the central height range of the entire aerosol layer (up to $2.5 \mathrm{~km}$ height) are shown in Fig. 12. The trajectories indicate an airflow from western to northern directions. They partly crossed the Caspian Sea, the saline lake Garabogazköl Aylagy (forming a lagoon of the Caspian Sea), and the Aral Sea (now Aralkum desert). We hypothesize that the background aerosol, detected between 1.6 and $2.5 \mathrm{~km}$ height, showing a moderate linear depolarization ratio of close to $20 \%$ and a low lidar ratio of $23 \mathrm{sr}$, mainly consists of dry salt particles. A similar signature of enhanced light depolarization in combination with lidar ratios around $25 \mathrm{sr}$ was found by Haarig et al. (2017b) for dried sea salt particles over the remote tropical Atlantic.

The analysis of the backward trajectories for all 45 background aerosol layers (with particle extinction coefficients $<30 \mathrm{Mm}^{-1}$ ) revealed that the prevailing, regional airflow was from western to northeastern directions, i.e., from the desiccating saline Lake Urmia in northwestern Iran, the Garabogazköl Aylagy, and Aral Sea to Lake Baikal. There are about 400 desiccating lakes with an area of $<10 \mathrm{~km}^{2}$ and 50 lakes with an area $>100 \mathrm{~km}^{2}$ in Central Asia basically fed by glacier meltwater. Dry lakes and saline playas are a sig- 


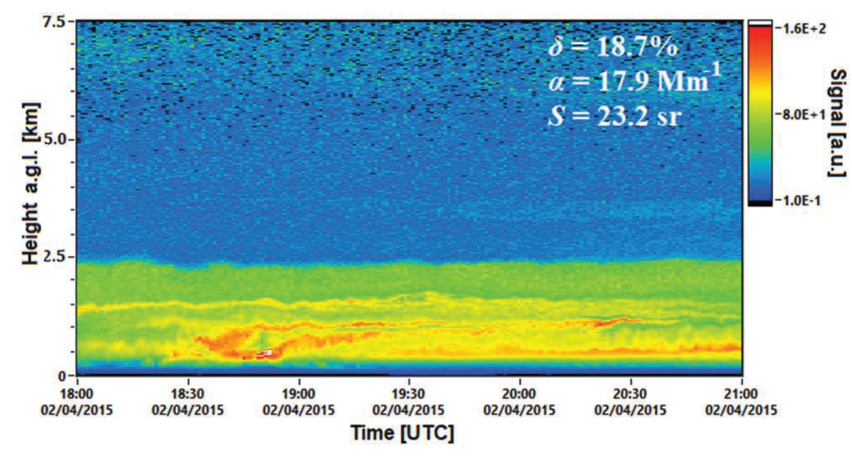

Figure 11. $1064 \mathrm{~nm}$ range-corrected signal (in arbitrary units) observed with lidar at Dushanbe, Tajikistan, on 2 April 2015, 18:0021:00 UTC (23:00-02:00 local time). The given numbers for the depolarization ratio $\delta$, the particle extinction coefficient $\alpha$, and the lidar ratio $S$ are mean values for the aerosol layer from 1.6 to $2.1 \mathrm{~km}$ height and the time period from 18:20 to 19:30 UTC. The incomplete laser-beam receiver-field-of-view overlap prohibits full signal detection up to about $500 \mathrm{~m}$ height.

nificant source of atmospheric dust in Asia according to the studies of Abuduwaili et al. (2010) and Issanova et al. (2015). Thus, there is an enormous potential for emission of polluted salt particles. In addition to direct emission, salt dust emitted over past decades, deposited, and integrated into the surface soil system is potentially available for resuspension.

In situ chemical characterization of $\mathrm{PM}_{10}$ (particulate matter with diameters $<10 \mu \mathrm{m}$ ) based on respective aerosol filter samples taken at the lidar field site at Dushanbe (a few kilometers apart from the city center) during the CADEX field campaign confirm our conclusions. The data showed significantly enhanced concentrations of calcium, potassium, fluoride as well as chloride. The dust calcium/iron ratio was twice as high as that observed for Saharan dust indicating a salt-enriched mineral dust in these particles (Fomba et al., 2019). According to Kandler and Scheuvens (2019) the high carbonate contents internally mixed with silicates observed in the aerosol samples indicate emissions from locations with high evaporation such as dry lake beds. Longterm measurements of the mineralogical composition of dust in Tajikistan also indicate that calcite and potassium mica are among the dominant minerals observed in the aerosols samples (Khodzhakhon et al., 2019). These in situ measurements performed during the CADEX campaigns and beyond confirm that salt-rich dust is present in this region.

Several lidar observations are in agreement with our background aerosol observations. Tesche et al. (2007) found rather low lidar ratios of around $20 \mathrm{sr}$ with lidar in northeastern China during background aerosol conditions (with low extinction coefficients) and an air mass transport from Mongolia and Central Asia in January 2005. Chen et al. (2013) used a multiwavelength Raman lidar (with nitrogen Raman channel at $387 \mathrm{~nm}$ ) in Kyrgyzstan and combined their observations with spectral sun photometer observations of AOT. In

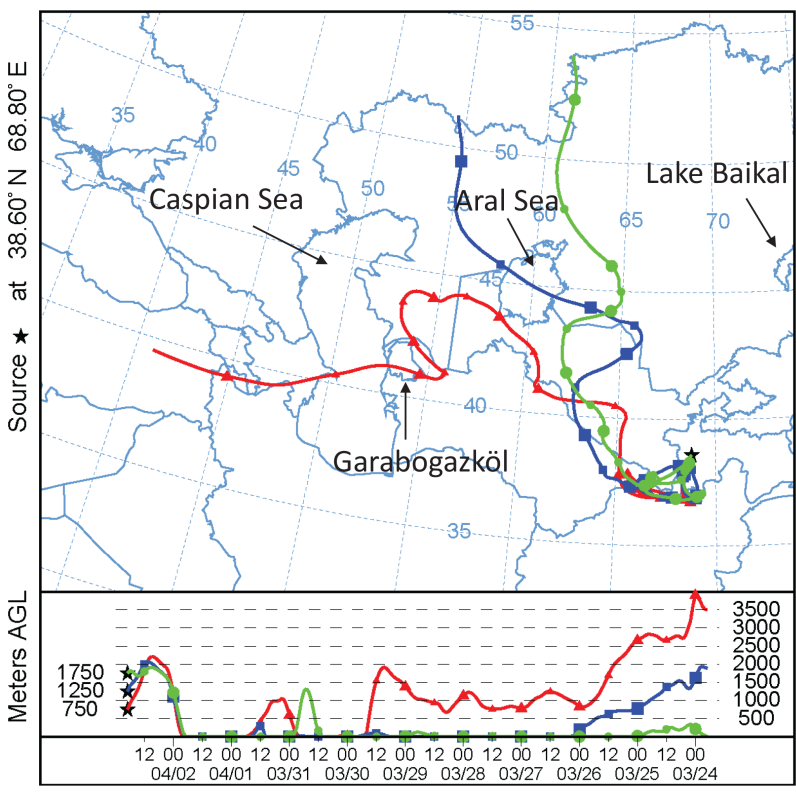

Figure 12. $10 \mathrm{~d}$ backward trajectories arriving at Dushanbe, Tajikistan, at $750 \mathrm{~m} \mathrm{(red),} 1250 \mathrm{~m}$ (blue), and $1750 \mathrm{~m}$ height on 2 April 2015, 19:00 UTC. The HYSPLIT model (Hybrid Single Particle Lagrangian Integrated Trajectory Model) (HYSPLIT, 2020; Stein et al., 2015; Rolph, 2016) is applied. Different sources of direct salt dust emissions are indicated. The right half of the Aral Sea is the Aralkum desert.

many cases, the retrieved lidar ratios were clearly below $30 \mathrm{sr}$ for the visible wavelength range. Dieudonné et al. (2015) also emphasized the comparably low lidar ratios, frequently from 32 to $40 \mathrm{sr}$ at $355 \mathrm{~nm}$ for Russian background aerosol. Khalesifard et al. (2020) and Ghomashi and Khalesifard (2019) found enhanced depolarization ratio up to 0.15 over the desiccating Lake Urmia in northwestern Iran caused by dried salt dust particles.

\section{Conclusion/Outlook}

Within a series of three articles (Hofer et al., 2017, 2020, and this study), we presented our CADEX lidar observations conducted from March 2015 to August 2016 in one of the hotspot regions for expected severe changes in environmental and climate conditions. An advanced continuously running multiwavelength polarization Raman lidar was deployed at Dushanbe, Tajikistan, in Central Asia. In this study, the full spectrum of aerosol mixtures from polluted urban haze conditions in winter to pure dust scenarios during heavy dust outbreak periods occurring during the summer half-year were discussed. The results were presented in terms of particle lidar ratios, linear depolarization ratios, and Ångström exponents measured at 2-3 wavelengths in the main aerosol layer typically reaching up to $3-5 \mathrm{~km}$ height. Overviews were given separately for each season of the year to cover the sea- 
sonal cycle. Surprisingly low lidar ratios for Central Asian dust, frequently below $40 \mathrm{sr}$ and especially during aerosol background conditions were found and may point to a nonnegligible contribution of salt dust emissions from desiccating lakes and the Aralkum desert and resuspension of deposited salt to the aerosol burden in Central Asia.

The three articles on our CADEX lidar observations can be regarded as the most systematic and densest, vertically resolved data set on Central Asian aerosol conditions published so far. The observations fill a gap in the characterization of aerosols in the center of the northern hemispheric dust belt from western Africa to eastern Asia. For lidar-based aerosol typing, especially with present and future spaceborne lidars such as CALIPSO/CALIOP, EarthCARE/ATLID, and Aeolus/ALADIN, important data sets in terms of particle linear depolarization ratio, lidar ratio, and Ångström exponent have been established for a region for which no data were available yet. The data are also required to support the basic data analysis of spaceborne lidar missions and harmonization of the overall spaceborne aerosol observations with lidar operated at different laser wavelengths. These data are also of great value for modeling groups dealing with environmental forecast and future climate prediction.

As an outlook, more studies on environmental conditions in the framework of well-established lidar networks and surface in situ aerosol measurement stations in the Middle East, Central Asia and eastern Asia would be desirable to improve atmospheric research and environmental forecast (e.g., of severe dust outbreaks). We just covered a period of 1.5 years with aerosol profile observations and need at least further 5-10 years of measurements to obtain a clear (climatological) view on Central Asian aerosol conditions and to derive conclusions on trends in the pollution and dust characteristics. More environment studies would also foster the collaboration with local atmospheric scientists and would upgrade their research potential. It is also hoped that the use of these observational data by weather bureaus and environmental services would sensitize the population to climatechange problems and encourage people to better take care of the environment and to avoid further environmental degradation. As a first step, our institute established a new long-term observational field site (an outpost station of EARLINET) at Dushanbe in June 2019, with a new Polly system (now with a diode-pumped laser source). It is planned to run this station over the next 5-10 years to improve aerosol and especially dust monitoring and to support modeling groups by offering continuous, height-resolved observations in Central Asia. The station will also serve as a ground-truth station for satellite missions.

Data availability. Polly lidar observations (level 0 data and measured signals) are in the PollyNET database (http://polly.rsd.tropos. de/, PollyNet, 2020). All analysis products are available at TROPOS upon request (info@tropos.de). The backward-trajectory anal- ysis has been supported by air mass transport computation with the NOAA (National Oceanic and Atmospheric Administration) HYSPLIT (HYbrid Single-Particle Lagrangian Integrated Trajectory) model (HYSPLIT, 2020).

Author contributions. JH and AA wrote the paper. JH performed the lidar data analysis supported by HB. KWF performed the chemical aerosol characterization. JH, DA, SFA, and ANM conducted the field experiment with support by RE and UW.

Competing interests. The authors declare that they have no conflict of interest.

Special issue statement. This article is part of the special issue "EARLINET aerosol profiling: contributions to atmospheric and climate research". It is not associated with a conference.

Acknowledgements. We would like to thank the Academy of Sciences of Tajikistan for the support during the CADEX campaign. Furthermore, we thank Konrad Müller, Bernd Heinold (TROPOS Leipzig), Georg Schettler (GFZ Potsdam), and Konrad Kandler (TU Darmstadt) for their contributions to the success of the CADEX campaign.

Financial support. The CADEX project was funded by the German Federal Ministry of Education and Research (BMBF) in the context of "Partnerships for sustainable problem solving in emerging and developing countries" under the grant number 01DK14014. The construction of a new lidar for permanent observations in Tajikistan is funded by the BMBF under the grant number 01LK1603A. This project has also received funding from the European Union's Horizon 2020 research and innovation program ACTRIS-2 Integrating Activities (H2020-INFRAIA2014-2015, grant agreement no. 654109) and from the European FP7 project by the European Union's Seventh Framework Program (FP7/2007-2013) collaborative project BACCHUS (grant agreement no. 603445).

The publication of this article was funded by the Open Access Fund of the Leibniz Association.

Review statement. This paper was edited by Eduardo Landulfo and reviewed by Ali Omar and Francisco Molero.

\section{References}

Abuduwaili, J., Liu, D., and Wu, G.: Saline dust storms and their ecological impacts in arid regions, J. Arid Land, 2, 144-150, https://doi.org/10.3724/SP.J.1227.2010.00144, 2010. 
Althausen, D., Abdullaev, S., and Hofer, J.: Scientists share results of dust belt research, EOS, Science News by AGU, 100, https://doi.org/10.1029/2019EO131683, 2019.

Ångström, A.: The parameters of atmospheric turbidity, Tellus, 16, 64-75, https://doi.org/10.1111/j.2153-3490.1964.tb00144.x, 1964.

Ansmann, A., Wandinger, U., Riebesell, M. A., Weitkamp, C., and Michaelis, W.: Independent measurement of extinction and backscatter profiles in cirrus clouds by using a combined Raman elastic-backscatter lidar, Appl. Optics, 31, 7113-7131, https://doi.org/10.1364/AO.31.007113, 1992.

Ansmann, A., Wagner, F., Müller, D., Althausen, D., Herber, A., von Hoyningen-Huene, W., and Wandinger, U.: European pollution outbreaks during ACE 2: Optical particle properties inferred from multiwavelength lidar and star-Sun photometry, J. Geophys. Res.-Atmos., 107, 4259, https://doi.org/10.1029/2001JD001109, 2002.

Ansmann, A., Wandinger, U., Le Rille, O., Lajas, D., and Straume, A. G.: Particle backscatter and extinction profiling with the spaceborne high-spectral-resolution Doppler lidar ALADIN: methodology and simulations, Appl. Optics, 46, 6606-6622, https://doi.org/10.1364/AO.46.006606, 2007.

Ansmann, A., Mamouri, R.-E., Hofer, J., Baars, H., Althausen, D., and Abdullaev, S. F.: Dust mass, cloud condensation nuclei, and ice-nucleating particle profiling with polarization lidar: updated POLIPHON conversion factors from global AERONET analysis, Atmos. Meas. Tech., 12, 4849-4865, https://doi.org/10.5194/amt-12-4849-2019, 2019.

Baars, H., Kanitz, T., Engelmann, R., Althausen, D., Heese, B., Komppula, M., Preißler, J., Tesche, M., Ansmann, A., Wandinger, U., Lim, J.-H., Ahn, J. Y., Stachlewska, I. S., Amiridis, V., Marinou, E., Seifert, P., Hofer, J., Skupin, A., Schneider, F., Bohlmann, S., Foth, A., Bley, S., Pfüller, A., Giannakaki, E., Lihavainen, H., Viisanen, Y., Hooda, R. K., Pereira, S. N., Bortoli, D., Wagner, F., Mattis, I., Janicka, L., Markowicz, K. M., Achtert, P., Artaxo, P., Pauliquevis, T., Souza, R. A. F., Sharma, V. P., van Zyl, P. G., Beukes, J. P., Sun, J., Rohwer, E. G., Deng, R., Mamouri, R.-E., and Zamorano, F.: An overview of the first decade of PollyNET: an emerging network of automated Raman-polarization lidars for continuous aerosol profiling, Atmos. Chem. Phys., 16, 5111-5137, https://doi.org/10.5194/acp16-5111-2016, 2016.

Bohlmann, S., Baars, H., Radenz, M., Engelmann, R., and Macke, A.: Ship-borne aerosol profiling with lidar over the Atlantic Ocean: from pure marine conditions to complex dust-smoke mixtures, Atmos. Chem. Phys., 18, 9661-9679, https://doi.org/10.5194/acp-18-9661-2018, 2018.

Burton, S. P., Ferrare, R. A., Hostetler, C. A., Hair, J. W., Rogers, R. R., Obland, M. D., Butler, C. F., Cook, A. L., Harper, D. B., and Froyd, K. D.: Aerosol classification using airborne High Spectral Resolution Lidar measurements - methodology and examples, Atmos. Meas. Tech., 5, 73-98, https://doi.org/10.5194/amt-5-732012, 2012.

Burton, S. P., Hair, J. W., Kahnert, M., Ferrare, R. A., Hostetler, C. A., Cook, A. L., Harper, D. B., Berkoff, T. A., Seaman, S. T., Collins, J. E., Fenn, M. A., and Rogers, R. R.: Observations of the spectral dependence of linear particle depolarization ratio of aerosols using NASA Langley airborne High Spec- tral Resolution Lidar, Atmos. Chem. Phys., 15, 13453-13473, https://doi.org/10.5194/acp-15-13453-2015, 2015.

Chen, B. B., Sverdlik, L. G., Imashev, S. A., Solomon, P. A., Lantz, J., Schauer, J. J., Shafer, M. M., Artamonova, M. S., and Carmichael, G. R.: Lidar Measurements of the Vertical Distribution of Aerosol Optical and Physical Properties over Central Asia, Int. J. Atmos. Sci., 2013, 261546, https://doi.org/10.1155/2013/261546, 2013.

Dai, G., Althausen, D., Hofer, J., Engelmann, R., Seifert, P., Bühl, J., Mamouri, R.-E., Wu, S., and Ansmann, A.: Calibration of Raman lidar water vapor profiles by means of AERONET photometer observations and GDAS meteorological data, Atmos. Meas. Tech., 11, 2735-2748, https://doi.org/10.5194/amt11-2735-2018, 2018.

Dieudonné, E., Chazette, P., Marnas, F., Totems, J., and Shang, X.: Lidar profiling of aerosol optical properties from Paris to Lake Baikal (Siberia), Atmos. Chem. Phys., 15, 5007-5026, https://doi.org/10.5194/acp-15-5007-2015, 2015.

Engelmann, R., Kanitz, T., Baars, H., Heese, B., Althausen, D., Skupin, A., Wandinger, U., Komppula, M., Stachlewska, I. S., Amiridis, V., Marinou, E., Mattis, I., Linné, H., and Ansmann, A.: The automated multiwavelength Raman polarization and water-vapor lidar PollyXT: the neXT generation, Atmos. Meas. Tech., 9, 1767-1784, https://doi.org/10.5194/amt-9-1767-2016, 2016.

Fernald, F. G.: Analysis of atmospheric lidar observations: some comments, Appl. Optics, 23, 652-653, https://doi.org/10.1364/AO.23.000652, 1984.

Filioglou, M., Giannakaki, E., Backman, J., Kesti, J., Hirsikko, A., Engelmann, R., O'Connor, E., Leskinen, J. T. T., Shang, X., Korhonen, H., Lihavainen, H., Romakkaniemi, S., and Komppula, M.: Optical and geometrical aerosol particle properties over the United Arab Emirates, Atmos. Chem. Phys., 20, 8909-8922, https://doi.org/10.5194/acp-20-8909-2020, 2020.

Flamant, P., Cuesta, J., Denneulin, M.-L., Dabas, A., and Huber, D.: ADM-Aeolus retrieval algorithms for aerosol and cloud products, Tellus A, 60, 273-286, https://doi.org/10.1111/j.16000870.2007.00287.x, 2008.

Fomba, K. W., Müller, K., Hofer, J., Makhmudov, A. N., Althausen, Nazarov, B. I., Abdullaev, S. F., and Herrmann, H.: Variations of the aerosol chemical composition during Asian dust storm at Dushanbe, Tajikistan, in: Proceedings of the Central Asian Dust Conference (CADUC), Dushanbe, Tajikistan, 8-12 April 2019, E3S Web Conf., 99, 03007, https://doi.org/10.1051/e3sconf/20199903007, 2019.

Freudenthaler, V., Esselborn, M., Wiegner, M., Heese, B., Tesche, M., Ansmann, A., Müller, D., Althausen, D., Wirth, M., Fix, A., Ehret, G., Knippertz, P., Toledano, C., Gasteiger, J., Garhammer, M., and Seefeldner, M.: Depolarization ratio profiling at several wavelengths in pure Saharan dust during SAMUM 2006, Tellus B, 61, 165-179, https://doi.org/10.1111/j.16000889.2008.00396.x, 2009.

Ghomashi, F. and Khalesifard, H. R.: CALIPSO Recordings and Categorization of Atmospheric Aerosols over the Urmia Lake, in: Proceedings of the Central Asian Dust Conference (CADUC), Dushanbe, Tajikistan, 8-12 April 2019, E3S Web Conf., 99, 01005, https://doi.org/10.1051/e3sconf/20199901005, 2019.

Giannakaki, E., Balis, D. S., Amiridis, V., and Zerefos, C.: Optical properties of different aerosol types: seven years 
of combined Raman-elastic backscatter lidar measurements in Thessaloniki, Greece, Atmos. Meas. Tech., 3, 569-578, https://doi.org/10.5194/amt-3-569-2010, 2010.

Groß, S., Tesche, M., Freudenthaler, V., Toledano, C., Wiegner, M., Ansmann, A., Althausen, D., and Seefeldner, M.: Characterization of Saharan dust, marine aerosols and mixtures of biomassburning aerosols and dust by means of multi-wavelength depolarization and Raman lidar measurements during SAMUM 2, Tellus B, 64, 706-724, https://doi.org/10.1111/j.16000889.2011.00556.x, 2011.

Groß, S., Esselborn, M., Weinzierl, B., Wirth, M., Fix, A., and Petzold, A.: Aerosol classification by airborne high spectral resolution lidar observations, Atmos. Chem. Phys., 13, 2487-2505, https://doi.org/10.5194/acp-13-2487-2013, 2013.

Guerrero-Rascado, J. L., Olmo, F. J., Avilés-Rodríguez, I., NavasGuzmán, F., Pérez-Ramírez, D., Lyamani, H., and Alados Arboledas, L.: Extreme Saharan dust event over the southern Iberian Peninsula in september 2007: active and passive remote sensing from surface and satellite, Atmos. Chem. Phys., 9, 84538469, https://doi.org/10.5194/acp-9-8453-2009, 2009.

Haarig, M., Ansmann, A., Althausen, D., Klepel, A., Groß, S., Freudenthaler, V., Toledano, C., Mamouri, R.-E., Farrell, D. A., Prescod, D. A., Marinou, E., Burton, S. P., Gasteiger, J., Engelmann, R., and Baars, H.: Triple-wavelength depolarizationratio profiling of Saharan dust over Barbados during SALTRACE in 2013 and 2014, Atmos. Chem. Phys., 17, 10767-10794, https://doi.org/10.5194/acp-17-10767-2017, 2017a.

Haarig, M., Ansmann, A., Gasteiger, J., Kandler, K., Althausen, D., Baars, H., Radenz, M., and Farrell, D. A.: Dry versus wet marine particle optical properties: RH dependence of depolarization ratio, backscatter, and extinction from multiwavelength lidar measurements during SALTRACE, Atmos. Chem. Phys., 17, 1419914217, https://doi.org/10.5194/acp-17-14199-2017, 2017b.

Hofer, J., Althausen, D., Abdullaev, S. F., Makhmudov, A. N., Nazarov, B. I., Schettler, G., Engelmann, R., Baars, H., Fomba, K. W., Müller, K., Heinold, B., Kandler, K., and Ansmann, A.: Long-term profiling of mineral dust and pollution aerosol with multiwavelength polarization Raman lidar at the Central Asian site of Dushanbe, Tajikistan: case studies, Atmos. Chem. Phys., 17, 14559-14577, https://doi.org/10.5194/acp-17-145592017, 2017.

Hofer, J., Ansmann, A., Althausen, D., Engelmann, R., Baars, H., Abdullaev, S. F., and Makhmudov, A. N.: Long-term profiling of aerosol light extinction, particle mass, cloud condensation nuclei, and ice-nucleating particle concentration over Dushanbe, Tajikistan, in Central Asia, Atmos. Chem. Phys., 20, 4695-4711, https://doi.org/10.5194/acp-20-4695-2020, 2020.

Hu, Q., Wang, H., Goloub, P., Li, Z., Veselovskii, I., Podvin, T., Li, K., and Korenskiy, M.: The characterization of Taklamakan dust properties using a multi-wavelength Raman polarization lidar in Kashi, China, Atmos. Chem. Phys. Discuss., https://doi.org/10.5194/acp-2020-375, in review, 2020.

HYSPLIT(2020): HYSPLIT: HYbrid Single-Particle Lagrangian Integrated Trajectory model, backward trajectory calculation tool, available at: http://ready.arl.noaa.gov/HYSPLIT_traj.php, last access: 20 May, 2020.

Illingworth, A. J., Barker, H. W., Beljaars, A., Ceccaldi, M., Chepfer, H., Clerbaux, N., Cole, J., Delanoë, J., Domenech, C., Donovan, D. P., Fukuda, S., Hirakata, M., Hogan, R. J.,
Huenerbein, A., Kollias, P., Kubota, T., Nakajima, T., Nakajima, T. Y., Nishizawa, T., Ohno, Y., Okamoto, H., Oki, R., Sato, K., Satoh, M., Shephard, M. W., Velázquez-Blázquez, A., Wandinger, U., Wehr, T., and van Zadelhoff, G.-J.: The EarthCARE Satellite: The Next Step Forward in Global Measurements of Clouds, Aerosols, Precipitation, and Radiation, B. Am. Meteorol. Soc., 96, 1311-1332, https://doi.org/10.1175/BAMS-D-12$00227.1,2015$.

Issanova, G., Abuduwaili, J., Galayeva, O., Semenov, O., and Bazarbayeva, T.: Aeolian transportation of sand and dust in the Aral Sea region, Int. J. Environ. Sci. Te., 12, 3213-3224, https://doi.org/10.1007/s13762-015-0753-x, 2015.

Kandler, K. and Scheuvens, D.: Asian and Saharan dust from a chemical/mineralogical point of view: differences and similarities from bulk and single particle measurements, in: Proceedings of the Central Asian Dust Conference (CADUC), Dushanbe, Tajikistan, 8-12 April 2019, E3S Web Conf., 99, 03001, https://doi.org/10.1051/e3sconf/20199903001, 2019.

Kanitz, T., Ansmann, A., Engelmann, R., and Althausen, D.: Northsouth cross sections of the vertical aerosol distribution over the Atlantic Ocean from multiwavelength Raman/polarization lidar during Polarstern cruises, J. Geophys. Res.-Atmos., 118, 2643 2655, https://doi.org/10.1002/jgrd.50273, 2013.

Khalesifard, H. R., Panahifar, H., Ghomashi, F., Alizadeh, S., and Moradhaseli, R.: Monitoring atmospheric aerosols over the Urmia Lake by CALIPSO and a ground-based depolarized lidar, in: Proceedings of the 29th International Laser Radar Conference (ILRC), Hefei, Anhui, China, 24-28 June 2019, EPJ Web Conf., 237, 02025, https://doi.org/10.1051/epjconf/202023702025, 2020.

Khodzhakhon, M. I., Nazarov, B. I., Abdullaev, S. F., and Karieva, R. A.: Mineralogical compounds of the composition of the dust aerosol on the period of dust storms in Tajikistan, in: Proceedings of the Central Asian Dust Conference (CADUC), Dushanbe, Tajikistan, 8-12 April 2019, E3S Web Conf., 99, 03008, https://doi.org/10.1051/e3sconf/20199903008, 2019.

Kim, M.-H., Kim, S.-W., and Omar, A. H.: Dust Lidar Ratios Retrieved from the CALIOP Measurements Using the MODIS AOD as a Constraint, Remote Sens., 12, 251, https://doi.org/10.3390/rs12020251, 2020.

Klett, J. D.: Lidar inversion with variable backscatter/extinction ratios, Appl. Optics, 24, 1638-1643, https://doi.org/10.1364/AO.25.000833, 1985.

Li, L. and Sokolik, I. N.: Developing a Dust Emission Procedure for Central Asia, Air, Soil and Water Research, 10, 288, https://doi.org/10.1177/1178622117711939, 2017.

Liu, Z., Sugimoto, N., and Murayama, T.: Extinction-tobackscatter ratio of Asian dust observed with high-spectralresolution lidar and Raman lidar, Appl. Optics, 41, 2760-2767, https://doi.org/10.1364/AO.41.002760, 2002.

Lux, O., Lemmerz, C., Weiler, F., Marksteiner, U., Witschas, B., Rahm, S., Geiß, A., and Reitebuch, O.: Intercomparison of wind observations from the European Space Agency's Aeolus satellite mission and the ALADIN Airborne Demonstrator, Atmos. Meas. Tech., 13, 2075-2097, https://doi.org/10.5194/amt13-2075-2020, 2020.

Mamouri, R. E. and Ansmann, A.: Fine and coarse dust separation with polarization lidar, Atmos. Meas. Tech., 7, 3717-3735, https://doi.org/10.5194/amt-7-3717-2014, 2014. 
Mamouri, R.-E. and Ansmann, A.: Potential of polarization/Raman lidar to separate fine dust, coarse dust, maritime, and anthropogenic aerosol profiles, Atmos. Meas. Tech., 10, 3403-3427, https://doi.org/10.5194/amt-10-3403-2017, 2017.

Mamouri, R. E., Ansmann, A., Nisantzi, A., Kokkalis, P., Schwarz, A., and Hadjimitsis, D. G.: Low Arabian dust extinctionto-backscatter ratio, Geophys. Res. Lett., 40, 4762-4766, https://doi.org/10.1002/grl.50898, 2013.

Mattis, I., Ansmann, A., Müller, D., Wandinger, U., and Althausen, D.: Dual-wavelength Raman lidar observations of the extinctionto-backscatter ratio of Saharan dust, Geophys. Res. Lett., 29, 1306, https://doi.org/10.1029/2002GL014721, 2002.

Mattis, I., Ansmann, A., Müller, D., Wandinger, U., and Althausen, D.: Multiyear aerosol observations with dual-wavelength Raman lidar in the framework of EARLINET, J. Geophys. Res.-Atmos., 109, D13203, https://doi.org/10.1029/2004JD004600, 2004.

Mona, L., Amodeo, A., Pandolfi, M., and Pappalardo, G.: Saharan dust intrusions in the Mediterranean area: Three years of Raman lidar measurements, J. Geophys. Res.-Atmos., 111, D16203, https://doi.org/10.1029/2005JD006569, 2006.

Müller, D., Ansmann, A., Mattis, I., Tesche, M., Wandinger, U., Althausen, D., and Pisani, G.: Aerosol-type-dependent lidar ratios observed with Raman lidar, J. Geophys. Res.-Atmos., 112, D16202, https://doi.org/10.1029/2006JD008292, 2007.

Nicolae, D., Vasilescu, J., Talianu, C., Binietoglou, I., Nicolae, V., Andrei, S., and Antonescu, B.: A neural network aerosol-typing algorithm based on lidar data, Atmos. Chem. Phys., 18, 1451114537, https://doi.org/10.5194/acp-18-14511-2018, 2018.

Nisantzi, A., Mamouri, R. E., Ansmann, A., Schuster, G. L., and Hadjimitsis, D. G.: Middle East versus Saharan dust extinctionto-backscatter ratios, Atmos. Chem. Phys., 15, 7071-7084, https://doi.org/10.5194/acp-15-7071-2015, 2015.

Omar, A. H., Winker, D. M., Vaughan, M. A., Hu, Y., Trepte, C. R., Ferrare, R. A., Lee, K., Hostetler, C. A., Kittaka, C., Rogers, R. R., Kuehn, R. E., and Liu, Z.: The CALIPSO automated aerosol classification and lidar ratio selection algorithm, J. Atmos. Oceanic Tech., 26, 1994-2014, https://doi.org/10.1175/2009JTECHA1231.1, 2009.

Papagiannopoulos, N., Mona, L., Alados-Arboledas, L., Amiridis, V., Baars, H., Binietoglou, I., Bortoli, D., D’Amico, G., Giunta, A., Guerrero-Rascado, J. L., Schwarz, A., Pereira, S., Spinelli, N., Wandinger, U., Wang, X., and Pappalardo, G.: CALIPSO climatological products: evaluation and suggestions from EARLINET, Atmos. Chem. Phys., 16, 2341-2357, https://doi.org/10.5194/acp-16-2341-2016, 2016.

Papagiannopoulos, N., Mona, L., Amodeo, A., D’ Amico, G., Gumà Claramunt, P., Pappalardo, G., Alados-Arboledas, L., GuerreroRascado, J. L., Amiridis, V., Kokkalis, P., Apituley, A., Baars, H., Schwarz, A., Wandinger, U., Binietoglou, I., Nicolae, D., Bortoli, D., Comerón, A., Rodríguez-Gómez, A., Sicard, M., Papayannis, A., and Wiegner, M.: An automatic observation-based aerosol typing method for EARLINET, Atmos. Chem. Phys., 18, 1587915901, https://doi.org/10.5194/acp-18-15879-2018, 2018.

Pappalardo, G., Amodeo, A., Apituley, A., Comeron, A., Freudenthaler, V., Linné, H., Ansmann, A., Bösenberg, J., D’Amico, G., Mattis, I., Mona, L., Wandinger, U., Amiridis, V., AladosArboledas, L., Nicolae, D., and Wiegner, M.: EARLINET: towards an advanced sustainable European aerosol lidar network,
Atmos. Meas. Tech., 7, 2389-2409, https://doi.org/10.5194/amt7-2389-2014, 2014.

PollyNet: PollyNET lidar data base, available at: http://polly.rsd. tropos.de/, last access: 20 May 2020.

Preißler, J., Wagner, F., Guerrero-Rascado, J. L., and Silva, A. M.: Two years of free-tropospheric aerosol layers observed over Portugal by lidar, J. Geophys. Res.-Atmos., 118, 3676-3686, https://doi.org/10.1002/jgrd.50350, 2013.

Rittmeister, F., Ansmann, A., Engelmann, R., Skupin, A., Baars, H., Kanitz, T., and Kinne, S.: Profiling of Saharan dust from the Caribbean to western Africa - Part 1: Layering structures and optical properties from shipborne polarization/Raman lidar observations, Atmos. Chem. Phys., 17, 12963-12983, https://doi.org/10.5194/acp-17-12963-2017, 2017.

Rolph, G.: Real-time Environmental Applications and Display sYstem (READY) Website: http://ready.arl.noaa.gov (last access: 20 May 2020), 2016.

Rupakheti, D., Kang, S., Bilal, M., Gong, J., Xia, X., and Cong, Z.: Aerosol optical depth climatology over Central Asian countries based on Aqua-MODIS Collection 6.1 data: Aerosol variations and sources, Atmos. Environ., 207, 205-214, https://doi.org/10.1016/j.atmosenv.2019.03.020, 2019.

Sakai, T., Shibata, T., Iwasaka, Y., Nagai, T., Nakazato, M., Matsumura, T., Ichiki, A., Kim, Y.-S., Tamura, K., Troshkin, D., and Hamdi, S.: Case study of Raman lidar measurements of Asian dust events in 2000 and 2001 at Nagoya and Tsukuba, Japan, Atmos. Environ., 36, 5479-5489, https://doi.org/10.1016/S13522310(02)00664-7, 2002.

Shin, S.-K., Tesche, M., Kim, K., Kezoudi, M., Tatarov, B., Müller, D., and Noh, Y.: On the spectral depolarisation and lidar ratio of mineral dust provided in the AERONET version 3 inversion product, Atmos. Chem. Phys., 18, 12735-12746, https://doi.org/10.5194/acp-18-12735-2018, 2018.

Stein, A. F., Draxler, R. R., Rolph, G. D., Stunder, B. J. B., Cohen, M. D., and Ngan, F.: NOAA's HYSPLIT atmospheric transport and dispersion modeling system, B. Am. Meteorol. Soc., 96, 2059-2077, https://doi.org/10.1175/BAMS-D-14$00110.1,2015$

Stoffelen, A., Pailleux, J., Källén, E., Vaughan, J. M., Isaksen, L., Flamant, P., Wergen, W., Andersson, E., Schyberg, H., Culoma, A., Meynart, R., Endemann, M., and Ingmann, P.: The atmospheric dynamics mission for global wind field measurement, B. Am. Meteorol. Soc., 86, 73-88, https://doi.org/10.1175/BAMS86-1-73, 2005.

Sugimoto, N. and Lee, C. H.: Characteristics of dust aerosols inferred from lidar depolarization measurements at two wavelengths, Appl. Optics, 45, 7468-7474, https://doi.org/10.1364/AO.45.007468, 2006.

Tesche, M., Ansmann, A., Müller, D., Althausen, D., Engelmann, R., Hu, M., and Zhang, Y.: Particle backscatter, extinction, and lidar ratio profiling with Raman lidar in south and north China, Appl. Optics, 46, 6302-6308, https://doi.org/10.1364/AO.46.006302, 2007.

Tesche, M., Groß, S., Ansmann, A., Müller, D., Althausen, D., Freudenthaler, V., and Esselborn, M.: Profiling of Saharan dust and biomass-burning smoke with multiwavelength polarization Raman lidar at Cape Verde, Tellus B, 63, 649-676, https://doi.org/10.1111/j.1600-0889.2011.00548.x, 2011. 
Veselovskii, I., Goloub, P., Podvin, T., Bovchaliuk, V., Derimian, Y., Augustin, P., Fourmentin, M., Tanre, D., Korenskiy, M., Whiteman, D. N., Diallo, A., Ndiaye, T., Kolgotin, A., and Dubovik, O.: Retrieval of optical and physical properties of African dust from multiwavelength Raman lidar measurements during the SHADOW campaign in Senegal, Atmos. Chem. Phys., 16, 70137028, https://doi.org/10.5194/acp-16-7013-2016, 2016.

Veselovskii, I., Hu, Q., Goloub, P., Podvin, T., Korenskiy, M., Derimian, Y., Legrand, M., and Castellanos, P.: Variability in lidarderived particle properties over West Africa due to changes in absorption: towards an understanding, Atmos. Chem. Phys., 20, 6563-6581, https://doi.org/10.5194/acp-20-6563-2020, 2020.

Voudouri, K. A., Siomos, N., Michailidis, K., Papagiannopoulos, N., Mona, L., Cornacchia, C., Nicolae, D., and Balis, D.: Comparison of two automated aerosol typing methods and their application to an EARLINET station, Atmos. Chem. Phys., 19, 10961-10980, https://doi.org/10.5194/acp-19-10961-2019, 2019.

Wandinger, U., Baars, H., Engelmann, R., Hünerbein, A., Horn, S., Kanitz, T., Donovan, D., van Zadelhoff, G.-J., Daou, D., Fischer, J., von Bismarck, J., Filipitsch, F., Docter, N., Eisinger, M., Lajas, D., and Wehr, T.: HETEAC: The Aerosol Classification Model for EarthCARE, in: The 27th International Laser Radar Conference (ILRC 27), edited by: Gross, B., Moshary, F., and Arend, M., New York, USA, 5-10 July 2015, EPJ Web Conf., 119, 01004, https://doi.org/10.1051/epjconf/201611901004, 2016.
Winker, D. M., Vaughan, M. A., Omar, A., Hu, Y., Powell, K. A., Liu, Z., Hunt, W. H., and Young, S. A.: Overview of the CALIPSO Mission and CALIOP Data Processing Algorithms, J. Atmos. Oceanic Tech., 26, 2310-2323, https://doi.org/10.1175/2009JTECHA1281.1, 2009.

Winker, D. M., Pelon, J., Coakley, J. A., Ackerman, S. A., Charlson, R. J., Colarco, P. R., Flamant, P., Fu, Q., Hoff, R. M., Kittaka, C., Kubar, T. L., Le Treut, H., Mccormick, M. P., Mégie, G., Poole, L., Powell, K., Trepte, C., Vaughan, M. A., and Wielicki, B. A.: The CALIPSO Mission: A Global 3D View of Aerosols and Clouds, B. Am. Meteorol. Soc., 91, 1211-1230, https://doi.org/10.1175/2010BAMS3009.1, 2010.

Witschas, B., Lemmerz, C., Geiß, A., Lux, O., Marksteiner, U., Rahm, S., Reitebuch, O., and Weiler, F.: First validation of Aeolus wind observations by airborne Doppler wind lidar measurements, Atmos. Meas. Tech., 13, 2381-2396, https://doi.org/10.5194/amt-13-2381-2020, 2020. 